\title{
DAMAGE RATIOS FOR DOMESTIC PROPERTY IN THE MAGNITUDE 7.2 1968 INANGAHUA, NEW ZEALAND, EARTHQUAKE
}

\author{
D.J. Dowrick ${ }^{1,2}$, D.A. Rhoades ${ }^{1,3}$ and P.N. Davenport ${ }^{1,3}$
}

\begin{abstract}
SUMMARY
An analysis of damage costs to domestic property in the $M_{w} 7.2$ Inangahua, New Zealand, earthquake of 23 May 1968 (U.T.) has allowed the evaluation of the vulnerability of domestic property for six intensity zones, from MM5 - MM10 inclusive. For no other earthquake worldwide has the vulnerability of any class of property been examined in so many intensity zones, and the effect of brittle chimneys on damage levels has been fully evaluated for the first time. The relative vulnerability of one and two storey houses has also been evaluated. The costs of damage were derived from about 8,000 insurance claims to the Earthquake and War Damage Commission. Damage ratios were evaluated for houses and their contents as functions of Modified Mercalli intensity. The indicators of vulnerability that were determined were the statistical distributions and mean values of damage ratios and the percentage of property items damaged for the six intensity zones. Comparisons have also been made with results from studies of other earthquakes.
\end{abstract}

\section{INTRODUCTION}

The Inangahua, New Zealand, earthquake which occurred at 5.24 a.m. on the $24^{\text {th }}$ May 1968 , had a magnitude of $M_{s}=7.4$ [1] and $M_{\mathrm{w}}=7.2$ [1]. It was predominantly a thrust event with the source rupture located beneath Inangahua. Although there was some secondary surface rupture in the vicinity of Inangahua the primary rupturing plane did not extend to the surface [2]. Peak ground accelerations ranging from $0.58 \mathrm{~g}$ to $0.015 \mathrm{~g}$ were recorded [3] at distances of $15 \mathrm{~km}$ to $304 \mathrm{~km}$ (Table 1). The earthquake was felt over most of the country from North Cape to Invercargill, with intensities ranging up to Modified Mercalli X (MM10) in the Inangahua area [4], as shown in the isoseismal map (Figure 1).

This earthquake was New Zealand's fourth most damaging in material damage cost terms in over one hundred years [5]. While it was fortunate in socio-economic terms that much of the area of strong shaking was in part of the lightly populated Southern Alps (Figure 2), the earthquake resulted in over 11,000 insurance claims (valid or invalid) being made on the New Zealand Earthquake and War Damage Commission (EWDC). About $85 \%$ of the claim documents still exist, in the care of the National Archives of New Zealand in Wellington. This is the largest database on damage costs for any event in New Zealand history, considerably greater than those of the two other significant events, the 1987 Edgecumbe and 1931 Hawke's Bay earthquakes. The damage costs for domestic property in the latter events have already been studied by two of the present authors [6 - 11]
As in the previous studies, in the present case the authors have statistically robust sets of data for studying the degree of damage to various classes of property in terms of damage ratio, $D_{r}$, defined as

$$
D_{r}=\frac{\text { Cost of damage to an Item }}{\text { Value of that Item }}
$$

The damage ratios are studied here as functions of intensity of ground shaking, and are related to the MM intensity isoseismals. The Value of each Item in equation (1) was first expressed in terms of the Insured Value, which in the case of houses was converted globally by intensity zone to Replacement Value, except for the MM10 zone, where the Replacement Value could be estimated directly for each house.

The present study offers an opportunity to enrich the database of damage ratios, and provide some insights into inter-event variability of damage ratios by comparing the damage ratios determined here with those from studies of other earthquakes [12 - 14]. The opportunity has been taken to go beyond our previous housing studies by (1) examining damage ratios over a wider range of intensities down to MM5, (2) separating out chimney damage over a range of intensities and (3) comparing one and two storey houses over a range of intensities. Also the authors have started the next phase of this study which considers microzoning effects and different classes of construction.

\footnotetext{
Institute of Geological \& Nuclear Sciences, Lower Hutt, New Zealand.

2 Fellow

Member
} 
Table 1: Recordings of peak ground acceleration (stronger component) in the Modified Mercalli intensity zones of the 1968 Inangahua earthquake (from Dowrick \& Sritharan [3]).

\begin{tabular}{llll}
\hline Intensity Zone & Site Name & PGA $(\mathbf{g})$ & $\boldsymbol{r}_{\boldsymbol{h}}$ \\
\hline MM9 & Reefton & 0.58 & 15 \\
\hline \multirow{2}{*}{ MM8 } & Murchison & 0.36 & 24 \\
& Westport & 0.30 & 24 \\
\hline \multirow{2}{*}{ MM6 } & Greymouth & 0.39 & 75 \\
& Hokitika & 0.17 & 109 \\
\hline \multirow{2}{*}{ MM5 } & Golden Downs & 0.092 & 74 \\
& Motueka & 0.075 & 110 \\
& Nelson & 0.080 & 118 \\
\hline & Cheviot & 0.049 & 145 \\
& Havelock & 0.030 & 154 \\
& Kaikoura & 0.052 & 152 \\
& Picton & 0.044 & 172 \\
& Christchurch 1 & 0.013 & 176 \\
& Christchurch 2 & 0.031 & 184 \\
& PEL & 0.015 & 246 \\
& Levin & 0.022 & 304 \\
& & & \\
& & &
\end{tabular}

$r_{h}=$ shortest distance to surface projection of rupture $(\mathrm{km})$.

\section{DESCRIPTION OF THE HOUSES IN THE AFFECTED AREA}

Within the area of stronger shaking, i.e. intensity $\geq$ MM7, there were very few houses of a type likely to collapse, namely brick bearing-wall houses. Most houses were timber framed with a variety of wall claddings, including weatherboard, corrugated iron, brick, artificial stone (concrete masonry), fibrous (asbestos) cement sheet, and stucco (roughcast) as illustrated in Figures 3 and 4. A small number of houses were made of (nominally) reinforced concrete blocks. In some cases ageing weatherboard had been protected from weathering by coverings of fibrous cement sheets or stucco.

While most roofs were made of corrugated iron, other materials were used including aluminium, tiles (various materials) and bituminous felt. The majority of houses were founded on unbraced timber piles, with some concrete piles and concrete strip footings also used. Nearly all houses had chimneys, most of which were of brittle materials (brick or concrete).

\section{THE DATA}

\subsection{General}

As in the author's previous studies [6 - 10], the approach used was to account for the total population of property of any given class in the area under consideration. For relating the data to intensity, the houses and household contents were divided into intensity zones, which were defined such that the MM7 intensity zone (for example) was the area between the MM7 and MM8 isoseismals as illustrated in Figure 2. The total number of houses in the intensity zones are given in Table 2, as derived from the counts of houses reported in the national census of 1966 [15] for MM5 - MM9, while the MM10 zone data were derived during this study.

A house was defined as a building containing mostly a single dwelling (occasionally two) and had either one or two storeys (Figures 3 and 4). Dwellings classed as flats in the census were excluded, as were holiday homes (or baches).

The costs of damage and the insured values were derived from the claims on the EWDC, of which about 8,000 valid claims related to houses and household contents, and which formed the starting point for the database. In a substantial number of cases the claims provided information on the nature of the damage and of the building, such as the foundation, wall and chimney materials, and a breakdown of the costs of repairs. It proved possible to split out the costs relating to chimney damage for $90 \%$ of the houses. It is noted that the EWDC claims represent the total cost of damage paid out for insured property, as there was no participation by the private sector insurance companies in underwriting earthquake damage in New Zealand in 1968. In addition it is noted that the claim payments were for repairs sufficient to restore property to its pre-earthquake condition [16], although less than this amount was paid out in some cases mainly in the MM10 zone. All costs are in 1968 dollars.

A valuable complementary source of data on construction materials, the nature and degree of damage, and uninsured houses, was the information collected in a survey conducted by the New Zealand Geological Survey (NZGS) [17] immediately after the earthquake. About 1,000 children from schools located mainly in the MM7-MM9 zones were helped by their parents or other adults to record data concerning their homes, as part of what was one of New Zealand's earliest microzoning studies relating to earthquake damage [16].

A great deal of effort was required to complete the database in relation to numbers of storeys, construction materials, addresses, and the data on undamaged houses. This phase of the work involved extensive field trips, use of the NZGS survey data sheets, the 1966 census reports, the 1969 Official Year Book [18], and reference to papers on damage to houses arising from the Inangahua earthquake reconnaissance mission of New Zealand engineers [19-21]. In order to make the rather slender subset of two-storey houses as statistically robust as possible, all of the two-storey hotels of house-type construction (Figure 4(b)) in the MM6-MM10 region were included in the database (see Table 2). These hotels were restricted in size to those with Insured Value up to $\$ 40,000$. 


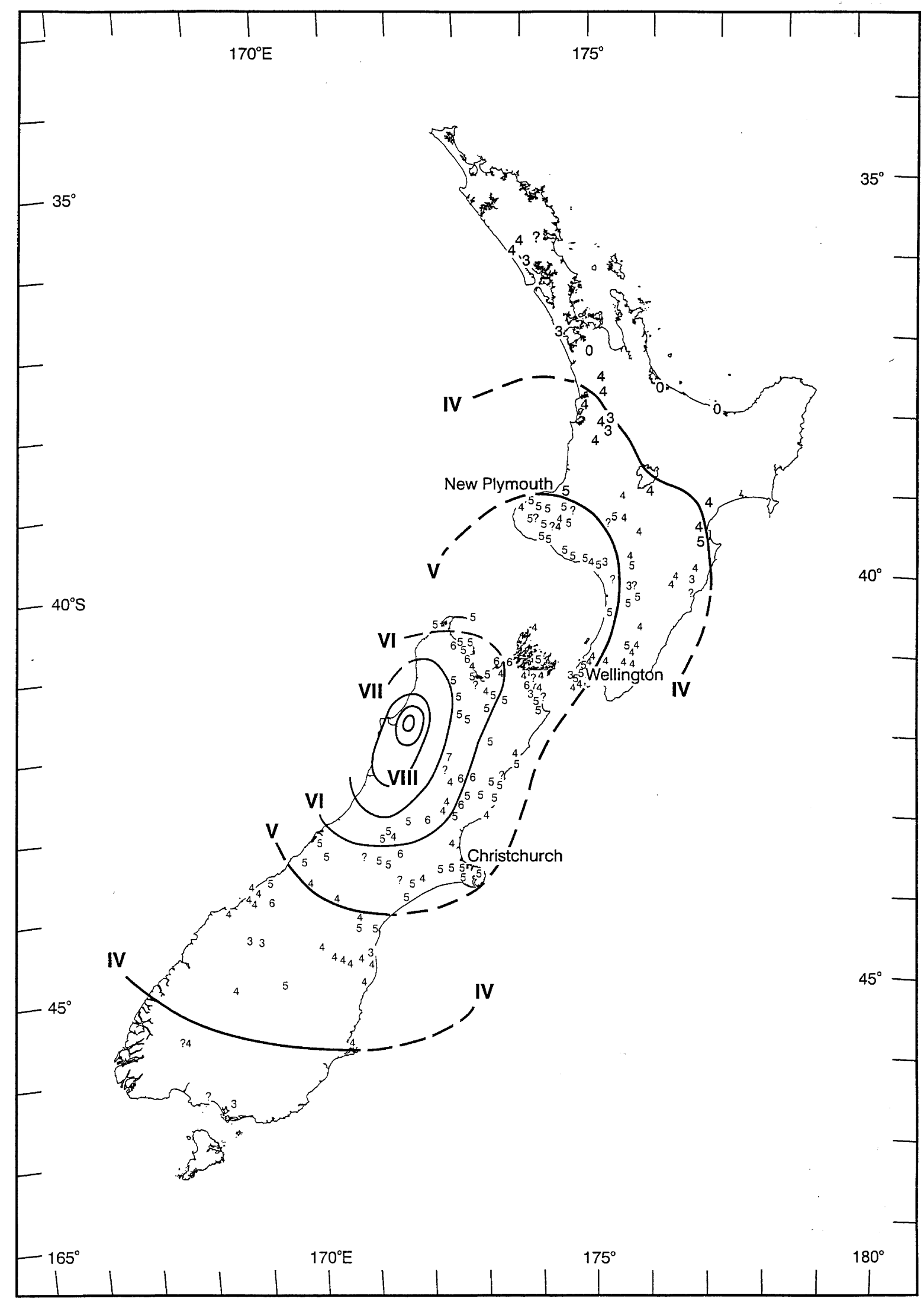

Figure 1: Map showing Modified Mercalli intensity isoseismals of the 1968 Inangahua earthquake (adapted from Adams et al. 1968 (4]). 


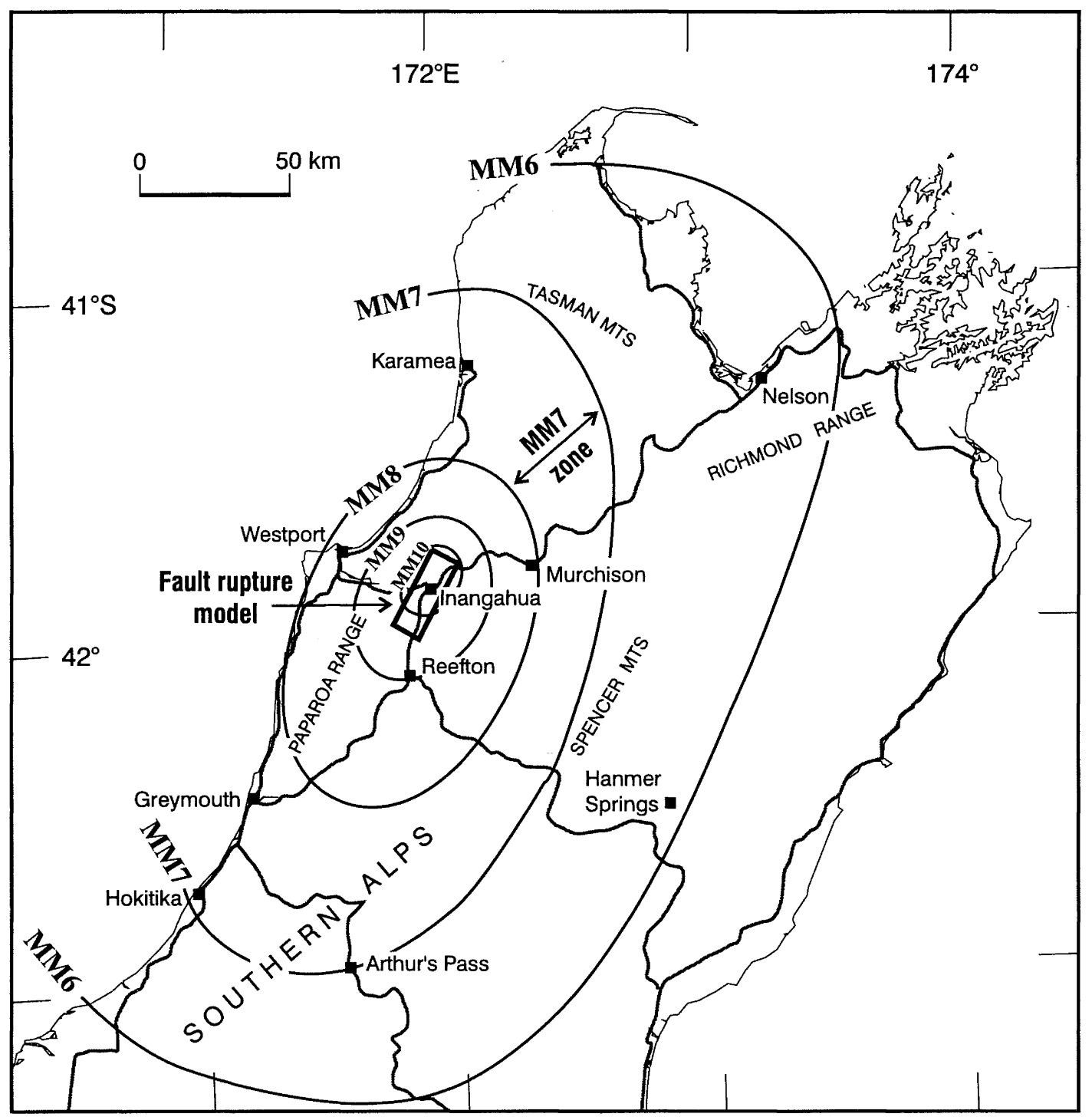

Figure 2: Map showing inner isoseismals, state highways and key placenames for the 1968 Inangahua earthquake. The fault rupture model of Haines in Reference [2] dips at $45^{\circ}$ with the top on the east side.

The NZGS survey data sheets referred to above comprised questionnaires for 995 houses. From an extensive study of the data sheets it was found that 610 of them correlated with insurance claims in our main database and 224 related to undamaged privately owned houses. Of the remainder, 108 were for public sector houses and 53 were for uninsured privately owned houses. A breakdown of this information by MM intensity zone is given in Table 3 .

These data are an essential aid to accounting for uninsured houses that must be deducted from the total populations of houses for the purpose of our damage ratio analyses. Public sector houses, i.e. those owned by central and local government, were not insured for earthquake damage at that time. Of the NZGS sample of 995 houses (Table 3), 10.9\% were public sector houses which is close to the national average figure of $9.6 \%$ for 1968 as derived from the Official Year Book data for that time [18]. It is also interesting to note from Table 3 that $5.3 \%$ of privately owned houses were uninsured which is somewhat less than insurance industry assumptions of about $10 \%$.

For household contents we have assumed that $30 \%$ of households were uninsured. This is a current insurance industry figure based on slender data, and happens to coincide with the percentage uninsured of 78 households in the Inangahua (MM10) area. The figure of $30 \%$ was also the middle of the range suggested for use in the Edgecumbe earthquake study [7].

The above data was used to derive the estimates of the total numbers of public sector houses and uninsured private sector houses given in Table 2. This was done by assuming that in each of the intensity zones MM6 - MM9, 10.9\% of the houses were in the public sector and $5.3 \%$ were otherwise uninsured. 


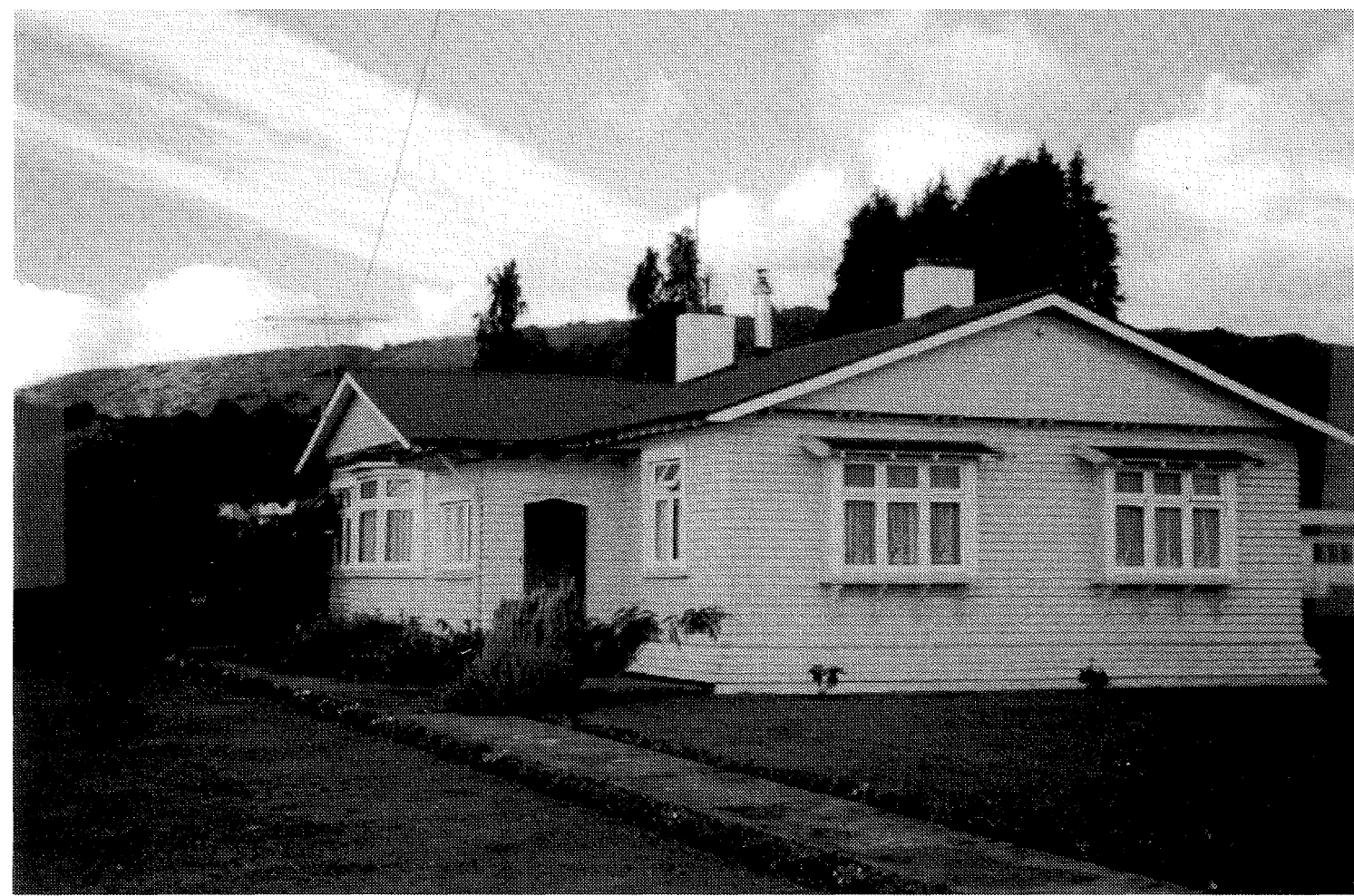

Figure 3(a): The most common type of pre-1968 West Coast house, one storey with a corrugated iron roof weatherboard wall cladding and piled foundations.

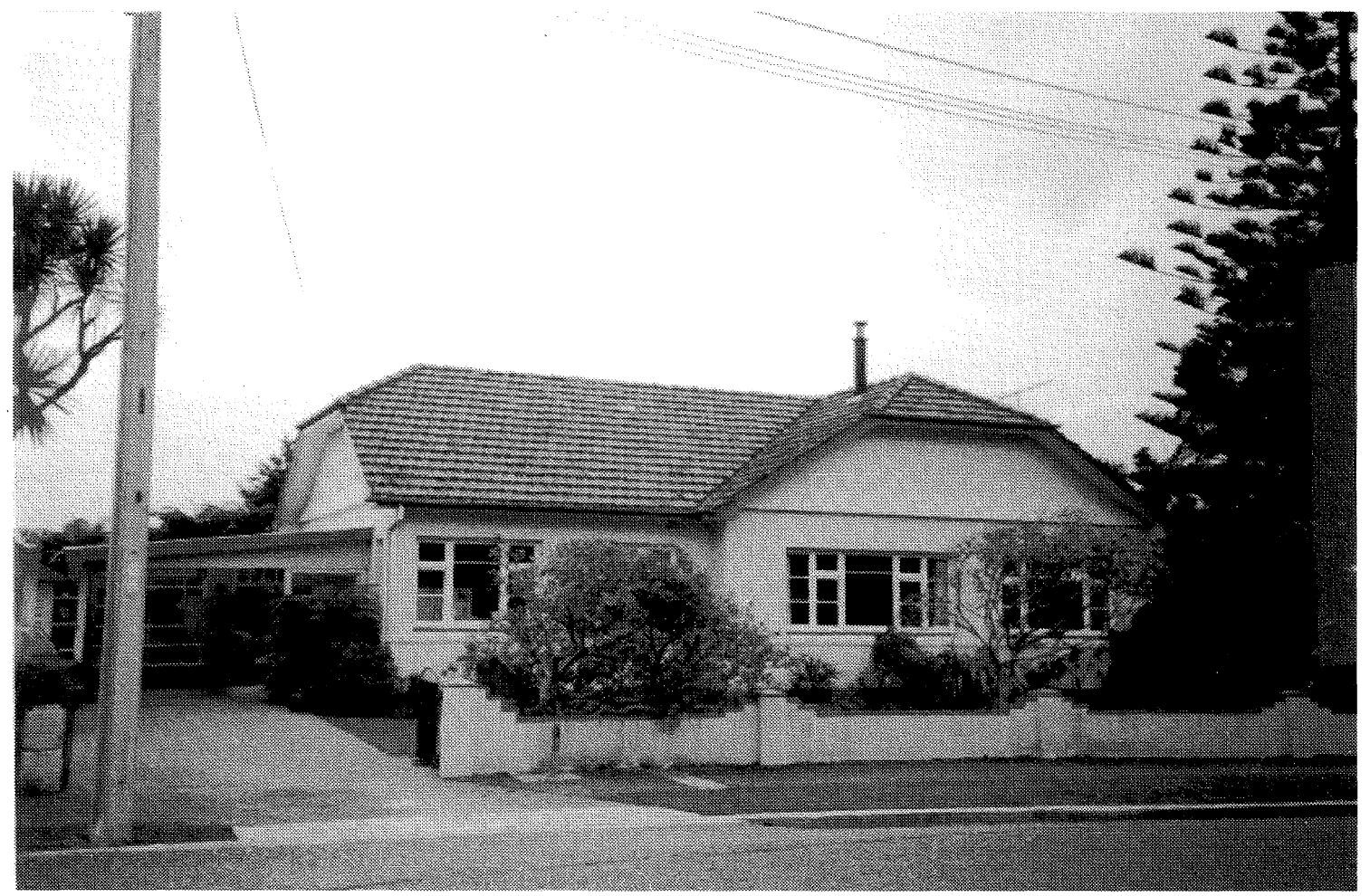

Figure 3(b): A pre-1968 one storey West Coast house with tiled roof, stucco veneer walls and concrete strip foundations. 


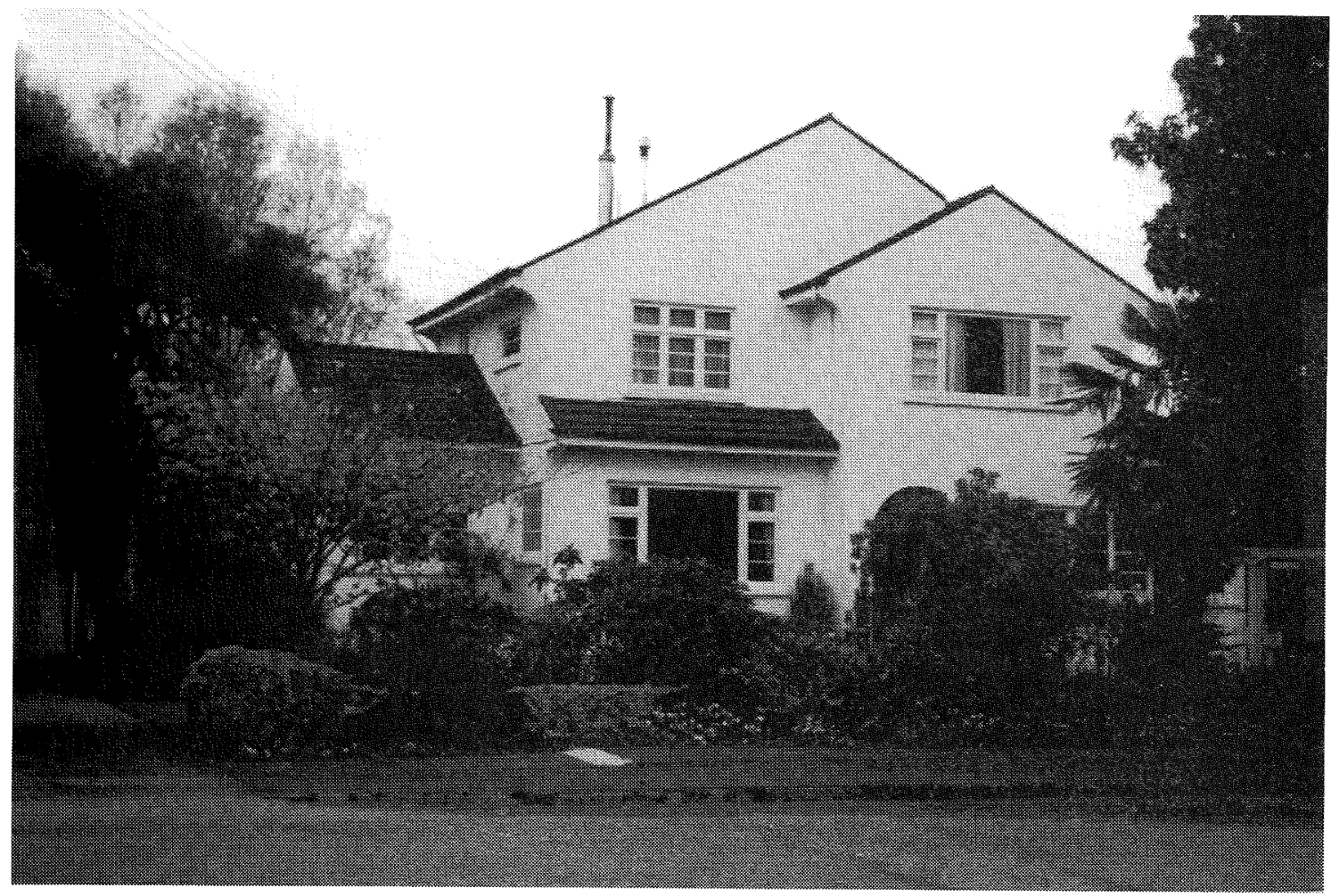

Figure 4(a): A pre-1968 two storey West Coast house with a tiled roof, stucco veneer walls and concrete strip foundation.

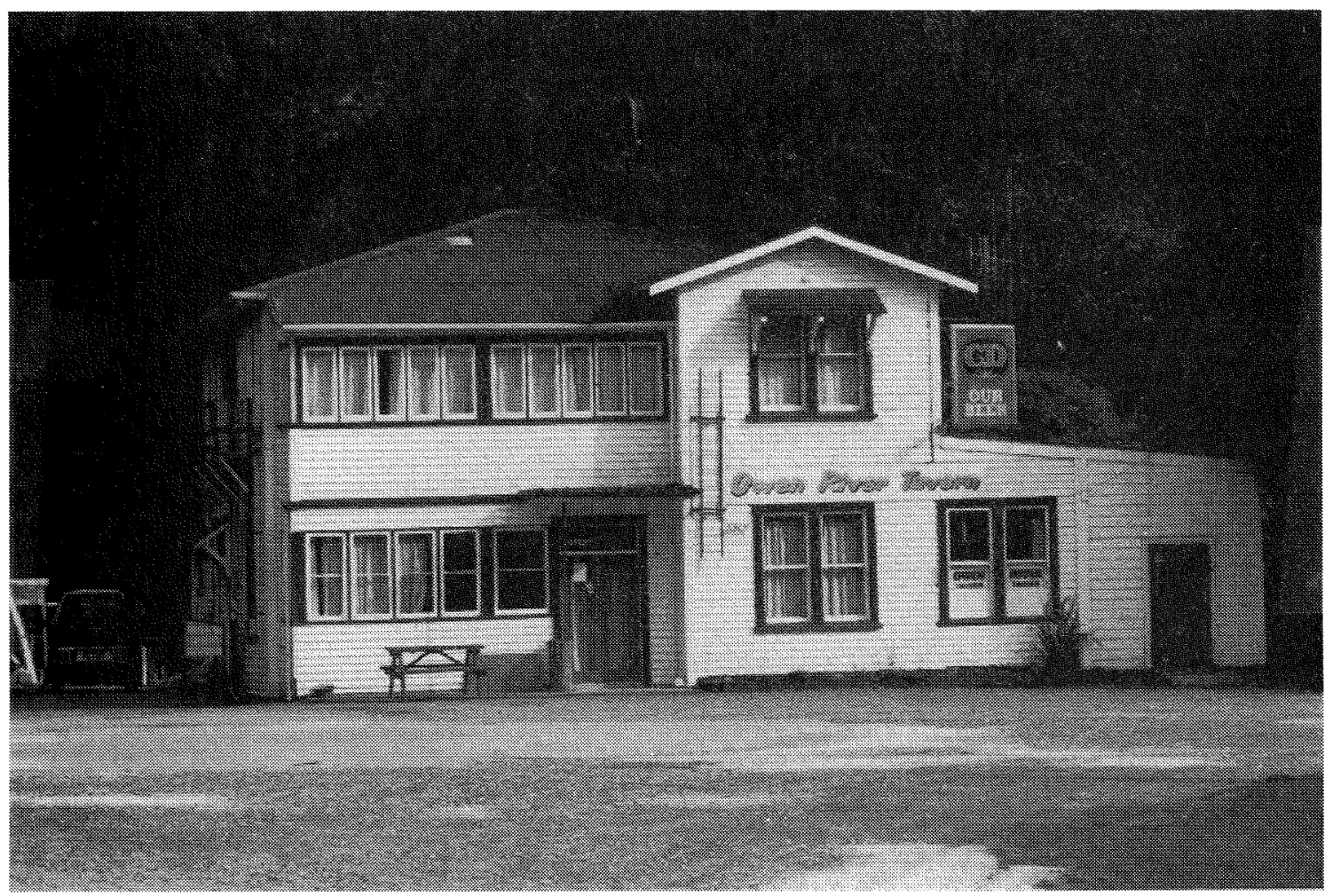

Figure 4(b): A typical pre-1968 two storey hotel of house style construction, with a corrugated iron roof, weatherboard wall cladding and piled foundation. 
Table 2: Statistics of numbers of houses of different insurance status and replacement values by intensity zone in the 1968 Inangahua earthquake.

\begin{tabular}{|c|c|c|c|c|c|c|}
\hline Intensity Zone & MM5 & MM6 & MM7 & MM8 & MM9 & MM10 \\
\hline \multicolumn{7}{|l|}{ Number of Houses } \\
\hline - $\quad$ All houses & 212,793 & 15,342 & 5,967 & 3,144 & 545 & c. 90 \\
\hline - Public Sector houses & 23,194 & 1,672 & 651 & 343 & 59 & c. 35 \\
\hline - Uninsured private houses & 11,278 & 813 & 316 & 166 & 29 & 0 \\
\hline - Insured houses & 178,321 & 12,867 & 5,000 & 2,635 & 457 & 55 \\
\hline $\begin{array}{l}\text { - } 2 \text { storey hotels and boarding houses } \\
\text { (house style) }\end{array}$ & $\nabla$ & 25 & 25 & 17 & 3 & 0 \\
\hline $\begin{array}{l}\text { Replacement Value of all insured houses } \\
\text { (\$NZ million 1968) }\end{array}$ & 1,456 & 117 & 38.9 & 20.0 & 3.31 & 0.37 \\
\hline
\end{tabular}

$\nabla \quad$ Not considered

Table 3: Damage, ownership and insurance statistics derived using survey data obtained immediately after the Inangahua earthquake by the NZ Geological Survey (Suggate \& Wood, 1979) [17]).

\begin{tabular}{|c|c|c|c|c|c|c|c|c|c|c|}
\hline \multirow[b]{3}{*}{$\begin{array}{l}\text { Intensity } \\
\text { Zone }\end{array}$} & \multicolumn{6}{|c|}{ Numbers of Houses } & & & \multirow{3}{*}{$\begin{array}{c}\% \\
\text { Public } \\
\text { Owned } \\
\end{array}$} & \multirow{3}{*}{$\begin{array}{c}\% \\
\text { Private } \\
\text { uninsured }\end{array}$} \\
\hline & \multirow[b]{2}{*}{ Total } & \multicolumn{2}{|c|}{ Private } & \multicolumn{2}{|c|}{ Public } & \multirow[b]{2}{*}{$\begin{array}{c}\text { Private } \\
\text { Uninsured }\end{array}$} & \multicolumn{2}{|c|}{$\%$ Damaged } & & \\
\hline & & $\begin{array}{c}\text { Damage } \\
\text { Claims }\end{array}$ & $\begin{array}{c}\text { No } \\
\text { damage }\end{array}$ & Damaged & $\begin{array}{c}\text { No } \\
\text { damage }\end{array}$ & & Private & All & & \\
\hline MM10 & 12 & 8 & 0 & 2 & 0 & 2 & 100 & 100 & NR & NR \\
\hline MM9 & 111 & 81 & 3 & 16 & 3 & 8 & 96.7 & 94.6 & 17.1 & 7.2 \\
\hline MM8 & 360 & 248 & 53 & 26 & 15 & 18 & 83.3 & 81.1 & 11.4 & 5.0 \\
\hline MM7 & 490 & 271 & 154 & 17 & 26 & 23 & 65.6 & 63.5 & 8.8 & 4.1 \\
\hline MM6 & 22 & 3 & 14 & 1 & 2 & 2 & NR & NR & NR & NR \\
\hline $\begin{array}{c}\text { Total } \\
\text { MM6-MM10 }\end{array}$ & 995 & 610 & 224 & 62 & 46 & 53 & NU & NU & 10.9 & 5.3 \\
\hline
\end{tabular}

$\mathrm{NR}=$ Not reliable. $\mathrm{NU}=$ Not useful

The value of each house is, of course, required for computing the damage ratio (Equation (1)). In this study, as in that of the Edgecumbe earthquake houses $[6,7]$ the only readily available value for each house was its Insured Value. An analysis of the data in the claims found a large geographical variation in the mean Insured Value, as reflected in the intensity zones. As seen in Table 4, the mean Insured Value for one storey houses ranged from $\$ 2,886$ in the MM8 Zone $(2,075$ houses mostly in Westport) to $\$ 3,642$ in the MM7 Zone (2,698 houses mostly in Greymouth and Hokitika), while for two storey houses it ranged from $\$ 5,920$ in the MM8 Zone (20 houses mostly in Westport) to $\$ 11,950$ in the MM5 Zone.

The general pattern, knowing the towns, cities and regions, is that there were larger houses in the more prosperous larger population areas (Table 4). The possibility that larger houses are more likely to be damaged needs to be considered. While it has been found in previous studies $[8,9]$ that two storey buildings are more damaged than one storey buildings, it has also been found [8] for houses of a given number of storeys (i.e. one storey) that size of house is not influential on damage level for medium to large size, while small houses may have been more damaged than larger ones.

Rather than basing the damage ratios on Insured Value as discussed above, it is mostly preferable to use Replacement Value of the houses. This was done here as follows. It is known from the Official Year Book [18], that the national average cost to build a new house in 1968 was $\$ 8,165$. Using the data in Table 5, it is assumed that the national mean Replacement Value of $\$ 8,165$ applies to the mean house floor area of $122 \mathrm{~m}^{2}$ obtained from a large sample of 20,272 houses in the Northwest of the South Island. For intensity zones MM5 - MM9, the mean Replacement Values for each 
intensity zone were scaled in proportion to the mean floor area of that zone.

Comparing the mean Replacement Values (Table 5) with the mean Insured Values (Table 4), it is seen that the insured value reflects the market value rather than the replacement value. This is supported by many comments in the claims, and also by the loss adjuster, Bird, who stated [16] that many buildings [in the West Coast area] were sub-standard and poorly maintained, and that property values were generally depressed with the consequences that in many cases the amounts of insurance were considerably less than the reinstatement costs

Table 4: Statistics of insured values of private sector houses.

\begin{tabular}{|c|ccc|ccc|}
\hline \multirow{2}{*}{$\begin{array}{c}\text { Intensity } \\
\text { Zone }\end{array}$} & \multicolumn{3}{|c|}{ Number of Houses } & \multicolumn{3}{c|}{ Mean Insured Value } \\
\cline { 2 - 7 } & 1 storey & 2 storey & 1 \& 2 storey & 1 storey & 2 storey & 1 \& 2 storey \\
\hline MM5 & $*$ & 41 & 568 & $*$ & 11,950 & 6,312 \\
MM6 & $*$ & 17 & 803 & $*$ & 7,929 & 5,799 \\
MM7 & 2,698 & 57 & 2,755 & 3,642 & 6,933 & 3,710 \\
MM8 & 2,075 & 20 & 2,095 & 2,886 & 5,920 & 2,915 \\
MM9 & 365 & 1 & 366 & 3,133 & 3,600 NR & 3,134 \\
MM10 & 49 & 1 & 50 & 3,357 & 600 NR & 3,410 \\
\hline MM5-MM10 & 6,516 & 138 & 6,654 & 3,819 & 8,426 & 3,914 \\
\hline
\end{tabular}

$\mathrm{NR}=$ Not reliable, based on one house only

- Not found in the present study.

Table 5: Statistics of floor areas and replacement values of pre-1969 houses

\begin{tabular}{llccc}
\hline \multicolumn{2}{c}{ Intensity Zone } & Number of houses ${ }^{(1)}$ & $\begin{array}{c}\text { Mean floor } \\
\text { area }{ }^{(1)}\left(\mathrm{m}^{2}\right)\end{array}$ & Mean Replacement Value \\
\hline MM 6 & Nelson area & 7,810 & 135.8 & 9,088 \\
MM7 & Greymouth/ Hokitika & 2,823 & 118.0 & 7,893 \\
MM8 & Westport/ Murchison & 1,531 & 113.2 & 7,583 \\
MM9 & Reefton & 348 & 108.1 & 7,235 \\
MM5 - MM10 & Sample & 20,272 & 122.0 & $8,165^{(2)}$ \\
\hline
\end{tabular}

(1) From Valuation New Zealand data

(2) From 1969 Official Year Book

For houses in the MM10 zone, the floor areas were estimated for each property, and the Replacement Value of the property was based on its floor area and the quality of the construction. The value per unit area was assigned individually to each house, ranging from $70 \%$ to $100 \%$ of the national average.

\subsection{Geographical distribution of houses}

As the statistical properties of the damage ratios of the property under consideration is being considered according to the populations of data within different intensity zones, it is important also to take account of the geographical distribution of the data within each intensity zone. By visual inspection of the isoseismal map (Figures 1 and 2), we find that the centroid of the locations of the houses in the intensity zones MM5 to MM8 are likely to be near the centre of their respective intensity zones, as the rural houses are reasonably uniformly distributed across the intensity zones and the largest population centres are near the centre of the respective intensity zone. Thus, the mean damage ratios and statistical distributions apply at the average intensity of these four zones, e.g. at MM8.5 in the MM8 intensity zones.

However, this is not the situation for the MM9 zone, as most of the population in this zone is located in Reefton which is just on the MM9 isoseismal. The only local intensity observation for Reefton township was MM9 and the peak ground acceleration recorded in Reefton was c. $0.6 \mathrm{~g}$ [3]. The centroid of the location of the MM9 houses is thus at intensity approximately MM9.1. 
In the MM10 zone most houses were in or near the village of Inangahua which is in the centre of the MM10 zone, where the intensity was likely to have been about MM10.5.

\section{DAMAGE COSTS}

An attempt has been made to find the total cost of damage to insured houses and household contents in this earthquake. The total cost of damage including the insurance deductible was recorded for each claim, including those small amounts where the value of the claim was assessed as being below the deductible (which was the greater of $\$ 10$ and one percent of the loss). Also included were the damage costs relating to a small number of claims that were declined for technical reasons, such as being filed too late or expired insurance, but where the damage costs were evidently valid.

The total costs of damage to houses and contents used in this study are given by intensity zone in Table 6 . The grand total for these costs comes to $\$ 1.67$ million compared to the total for domestic and non-domestic property paid out by the EWDC of approximately $\$ 2.4$ million. A striking feature of the costs of damage to houses is that about $78 \%$ of the total was caused by chimney damage.

Table 6: Summary of material damage costs $(\$ N Z 000)$ for private sector domestic property in the Inangahua earthquake.

\begin{tabular}{|c|rrr|rcc|c|}
\hline \multirow{2}{*}{$\begin{array}{c}\text { Intensity } \\
\text { Zone }\end{array}$} & \multicolumn{3}{|c|}{ Houses } & \multicolumn{3}{c|}{ 2 storey hotels } & Household \\
\cline { 2 - 8 } & $\begin{array}{l}\text { Non- } \\
\text { chimney }\end{array}$ & Chimney & Unknown & Non-chimney & Chimney & Unknown & Contents \\
\hline MM4 & 0.1 & 0.5 & 0 & 0 & 0 & 0 & 0.2 \\
MM5 & 21.3 & 14.0 & 6.6 & $\nabla$ & $\nabla$ & $\nabla$ & 0.6 \\
MM6 & 14.6 & 38.9 & 4.8 & 0.2 & 0.8 & 0 & 1.4 \\
MM7 & 77.9 & 473.8 & 55.4 & 14.5 & 7.5 & 0 & 38.9 \\
MM8 & 65.7 & 470.4 & 44.4 & 9.0 & 8.8 & 2.1 & 49.6 \\
MM9 & 20.8 & 84.6 & 2.9 & 2.2 & 4.1 & 0 & 14.3 \\
MM10 & 103.6 & 16.8 & 10.8 & 0 & 0 & 0 & 33.2 \\
\hline Total & & & & & 21.2 & 2.1 & 138.2 \\
\hline
\end{tabular}

*House style construction

$\nabla$ Not considered

\section{DAMAGE RATIOS}

The damage ratios presented below were calculated in terms of Replacement Values for houses and Insured Values for contents.

\subsection{Statistical distributions of damage ratios}

The damage ratio $\left(D_{r}\right)$ for each house and each parcel of contents was calculated as defined by equation (1) above. All other studies by two of the present authors [e.g. 6-10] of damage in other earthquakes have shown the shape of the statistical distribution of non-zero damage ratios for various classes of property to be well approximated by a truncated lognormal distribution. The lognormal distribution has the density function

$$
f(x)=\frac{1}{\sigma x \sqrt{2 \pi}} \exp \left[-\frac{1}{2}\left(\log _{c} x-\mu\right)^{2} / \sigma^{2}\right], \quad x>0
$$

In the truncated form of the distribution as fitted to damage ratios, there is a "spike" at 1, i.e.,
$P\left(D_{r}=1\right)=\int_{1}^{\infty} f(x) d x$. Here the parameters $\mu$ and $\sigma$ are approximated by the sample mean and standard deviation of the natural logarithm of the damage ratio of damaged items.

The estimates of the parameters $\mu$ and $\sigma$, found for the various data sets are given in Tables 7 and 8. Also tabulated are the numbers of damaged items $n$, and the total populations (damaged + undamaged) $N$.

\subsection{Mean damage ratios}

The mean damage ratio for all buildings in a given $\mathrm{MM}$ intensity zone is a useful parameter for various purposes [10], e.g. for comparing the earthquake resistance of different classes of property. Considering all $N$ buildings (damaged and undamaged) in an MM intensity zone, we give here two principal ways of defining the Mean $D_{r}$. Firstly

$\bar{D}_{r}=\frac{\sum_{i=1}^{n}[\text { cost of damage to building } i]}{\sum_{\mathrm{i}=1}^{\mathrm{N}}[\text { value of building } i]}$ 
where $n$ is the number of damaged buildings.

Secondly

$$
D_{r m}=\frac{\sum_{i=1}^{n}\left[D_{r_{i}}\right]}{N}
$$

In general $D_{r m}$ with its associated confidence limits is a more reliable and useful tool than $\bar{D}_{r}$ [10]. If derived from large, homogeneous populations, $\bar{D}_{r}$ and $D_{r m}$ tend to be similar in value, while for more inhomogeneous populations (with large ranges of replacement values and vulnerabilities) $\bar{D}_{r}$ and $D_{r m}$ may differ widely. The values of $\bar{D}_{r}$ and $D_{r m}$ for the various classes of domestic property considered in this study are presented in Tables 7 and 8 .

Table 7: Basic statistics of the distribution of damage ratios for household contents in the Inangahua earthquake

\begin{tabular}{lrrrrcc}
\hline Intensity Zone & $n$ & $N$ & $\mu$ & $\sigma$ & $D_{r m}$ & $\bar{D}_{r}$ \\
\hline MM5 & 12 & 124,825 & -4.75 & 1.59 & $2 \times 10^{-6}$ & $2 \times 10^{-6}$ \\
MM6 & 37 & 9,000 & -4.71 & 1.31 & $5.1 \times 10^{-5}$ & $5.0 \times 10^{-5}$ \\
MM7 & 1,170 & 3,502 & -4.66 & 1.06 & 0.0056 & 0.0050 \\
MM8 & 1,358 & 1,847 & -4.35 & 1.01 & 0.0154 & 0.0133 \\
MM9 & 280 & 321 & -4.04 & 1.02 & 0.0252 & 0.0220 \\
MM10 & 54 & 54 & -1.44 & 0.83 & 0.286 & 0.270 \\
\hline
\end{tabular}

It has been found in previous studies that the damage ratio is sometimes related to property value [11]. If it is, $\bar{D}_{r}$ and $D_{r m}$ tend to differ. For example, if higher valued properties tend to have higher damage ratios, then $\bar{D}_{r}$ tends to exceed $D_{r m}$. In the present study, as in the Napier earthquake study, the tendency is for $\bar{D}_{r}$ for houses to be less than $D_{r m}$, for most subsets. This indicates that lower valued houses tend to have higher damage ratios. Such a trend could arise from a number of causes, including under-estimation of the replacement values of low-valued properties, or by the costs associated with some of the main types of damage being independent of replacement value. Both elements may be present in this study. First, under-valuation of low-valued properties is likely to arise because replacement values are mostly derived from insured values. Secondly, the damage to brittle chimneys was an important contributor to repair costs for housing, and the cost of repairing chimney damage is not necessarily related to the replacement value of the whole building.

Next we compare the vulnerability of different classes of property in terms of their statistical distributions of mean damage ratios, proportions of population damaged, and uncertainties. In the graphs of $D_{r m}$ and $n / N$ that follow, the values for the MM9 zone are plotted at MM9.1 for the reasons discussed in Section 3.2.

\subsection{All houses and all damage}

Plots of cumulative probability of damage ratios in the Inangahua earthquake are shown for all houses by MM intensity in Figure 5(a). There are six intensity zones, MM5MM10, i.e. three more than were possible in our richest previous data set $[6,7]$. The shapes of the distributions have the now familiar lognormal form. While very small amounts of damage occur at MM5, Figure 5 shows that the amount of damage is very small and the practical threshold of damage is at MM6 for houses, especially those with brittle chimneys. This is consistent with the definitions of the MM intensity scale [22] (see Appendix 1), and confirms that the outer isoseismals (Figure 1) have been appropriately located.

When considering mean damage ratios, parallel effects are observed to those discussed above in terms of damage ratio distributions. Figure 5(b) shows plots of $D_{r m}$ for six intensity zones. The values of $D_{r m}$ (including all damage) for the Inangahua earthquake range up to 0.35 at $\mathrm{MM} 10$

The remaining key parameter in evaluating damage levels is the percentage of houses damaged, which is plotted against intensity in Figure 5(c) with values ranging up to $100 \%$ at MM10. When chimney damage is included, there is a plateau of $81 \%$ between MM8 and MM9. These percentages are calculated as $n / N$ from Tables 8 , where $n$ is the number of damaged houses including all claims with non-zero costs, where $n=617,832,2961,2146,372$ and 55 for MM5-MM10 respectively. When claims below the insurance deductible are excluded the counts of $n$ become 575, 707, 2930, 2133 , 371 and 55.

Special features of Figure 5 are discussed below in Section 5.4 
Table 8: Basic statistics of the distribution of damage ratios for various classes of houses in the Inangahua earthquake.

\begin{tabular}{|c|c|c|c|c|c|c|}
\hline Intensity Zone & $n$ & $N$ & $\mu$ & $\sigma$ & $D_{r m}$ & $\bar{D}_{r}$ \\
\hline \multicolumn{7}{|l|}{ MM5 Zone } \\
\hline Houses all costs & 617 & 178,321 & -5.03 & 0.91 & 0.00003 & 0.00003 \\
\hline Houses excluding chimney damage & 402 & 178,321 & -5.28 & 0.99 & 0.00002 & 0.00002 \\
\hline \multicolumn{7}{|l|}{ MM6 Zone } \\
\hline Houses all costs & 832 & 12,892 & -5.14 & 1.08 & 0.00066 & 0.00051 \\
\hline Houses excluding chimney damage & 262 & 12,892 & -5.92 & 1.21 & 0.00011 & 0.00014 \\
\hline \multicolumn{7}{|l|}{ MM7 Zone } \\
\hline \multicolumn{7}{|l|}{ Houses all costs } \\
\hline All & 2,961 & 5,025 & -3.75 & 0.96 & 0.021 & 0.016 \\
\hline 1 storey & 2,892 & 4,929 & -3.74 & 0.95 & 0.021 & 0.016 \\
\hline 2 storey & 69 & 96 & -4.08 & 1.25 & 0.022 & 0.020 \\
\hline \multicolumn{7}{|l|}{ Houses excluding chimney costs } \\
\hline All & 1,685 & 5,025 & -5.59 & 1.14 & 0.0024 & 0.0026 \\
\hline 1 storey & 1,639 & 4,929 & -5.60 & 1.13 & 0.0024 & 0.0022 \\
\hline 2 storey & 46 & 96 & -5.22 & 1.56 & 0.0063 & 0.0099 \\
\hline \multicolumn{7}{|l|}{ MM8 Zone } \\
\hline \multicolumn{7}{|l|}{ Houses all costs } \\
\hline All & 2,146 & 2,652 & -3.35 & 1.02 & 0.0441 & 0.0301 \\
\hline 1 storey & 2,110 & 2,612 & -3.43 & 1.02 & 0.0441 & 0.0300 \\
\hline 2 storey & 36 & 40 & -3.66 & 1.25 & 0.0437 & 0.0317 \\
\hline \multicolumn{7}{|l|}{ Houses excluding chimney costs } \\
\hline All & 1,113 & 2,652 & -5.23 & 1.16 & 0.0048 & 0.0040 \\
\hline 1 storey & 1,090 & 2,612 & -5.23 & 1.15 & 0.0046 & 0.0037 \\
\hline 2 storey & 23 & 40 & -5.22 & 1.82 & 0.0136 & 0.0118 \\
\hline \multicolumn{7}{|l|}{ MM9 Zone } \\
\hline \multicolumn{7}{|l|}{ Houses all costs } \\
\hline All & 372 & 460 & -3.21 & 1.01 & 0.0462 & 0.0346 \\
\hline 1 storey & 368 & 455 & -3.32 & 1.01 & 0.0459 & 0.0340 \\
\hline \multicolumn{7}{|l|}{ Houses excluding chimney costs } \\
\hline All & 272 & 460 & -5.146 & 1.30 & 0.0090 & 0.0071 \\
\hline 1 storey & 268 & 455 & -5.154 & 1.30 & 0.0088 & 0.0066 \\
\hline \multicolumn{7}{|l|}{ MM10 Zone } \\
\hline Houses all costs & 55 & 55 & -1.213 & 1.42 & 0.348 & 0.357 \\
\hline Houses excluding chimney costs & 55 & 55 & -1.778 & 1.51 & 0.299 & 0.305 \\
\hline
\end{tabular}

\subsection{Brittle Chimneys}

When considering chimney costs, all costs attributable to chimney failure have been included, i.e. direct costs of damage to the chimneys and fireplaces, plus all indirect costs of damage caused by the chimneys to house structure and finishes, including roof, ceilings, floors and walls.

First consider the distributions of damage ratios plotted in Figure 6(a) where the damage costs are restricted to those related to chimneys for intensities MM6-MM10. The plots show emphatically how chimney damage saturates at MM8, with the curves for MM8 and MM9 being almost indistinguishable. This is what should be expected from the definition of the MM intensity scale which states that at MM8 most unreinforced chimneys are damaged and many are brought down (See Appendix 1). This explains the surprising result shown in Figure 5(a), where it is seen that the damage ratio distributions for MM8 and MM9 are virtually identical when all damage is considered. Conversely the expected difference between MM8 and MM9 is seen when the dominating chimney damage is excluded (Figure 6(b)). Figure 6(c) further emphasises the enormous impact of brittle chimneys on the incidence and level of damage, through wide separation of the mean distributions and their $95 \%$ confidence limits at intensity MM8 for the cases including and excluding chimney damage. 

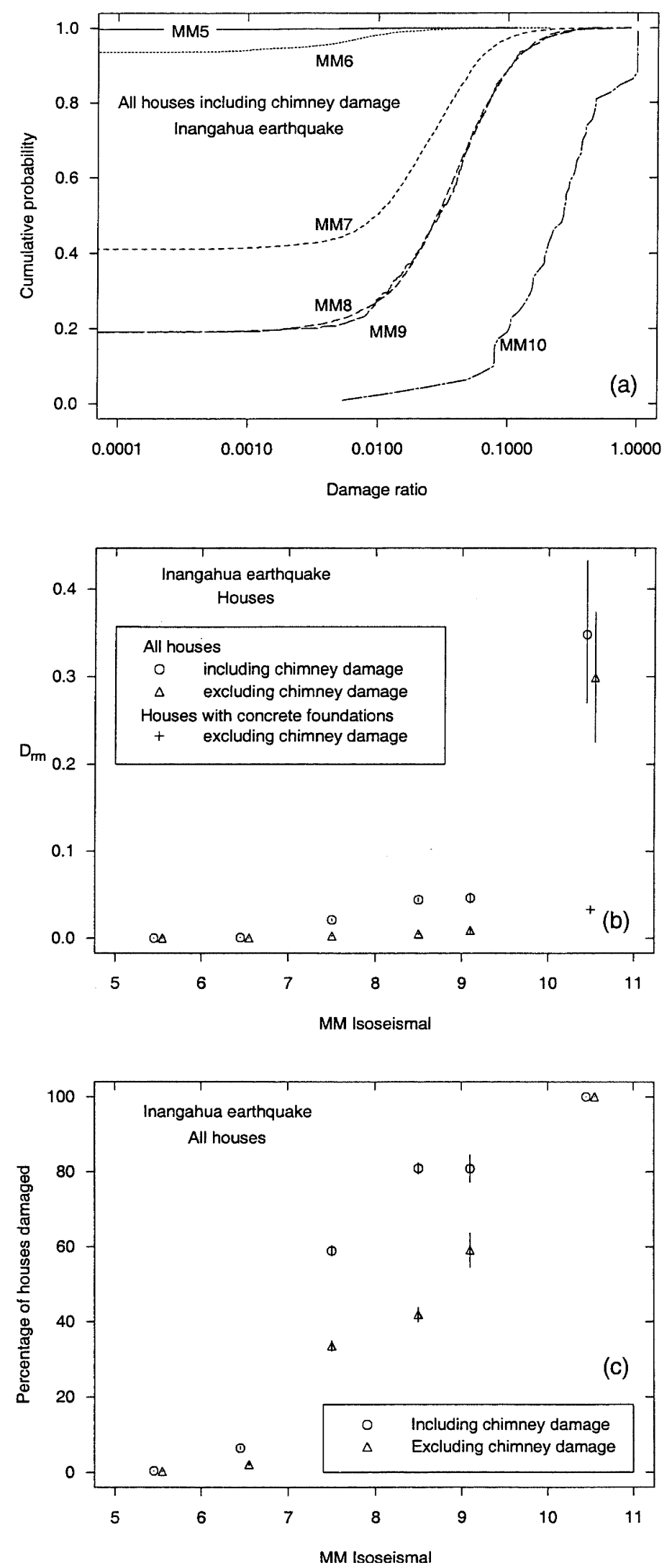

Figure 5: Three measures of vulnerability plotted as functions of MM intensity for all houses in the Inangahua earthquake: (a) Cumulative probability distributions of damage ratio, (b) $D_{r m}$ and its $95 \%$ confidence limits, and (c) Percentage of houses damaged with its $95 \%$ confidence limits. 

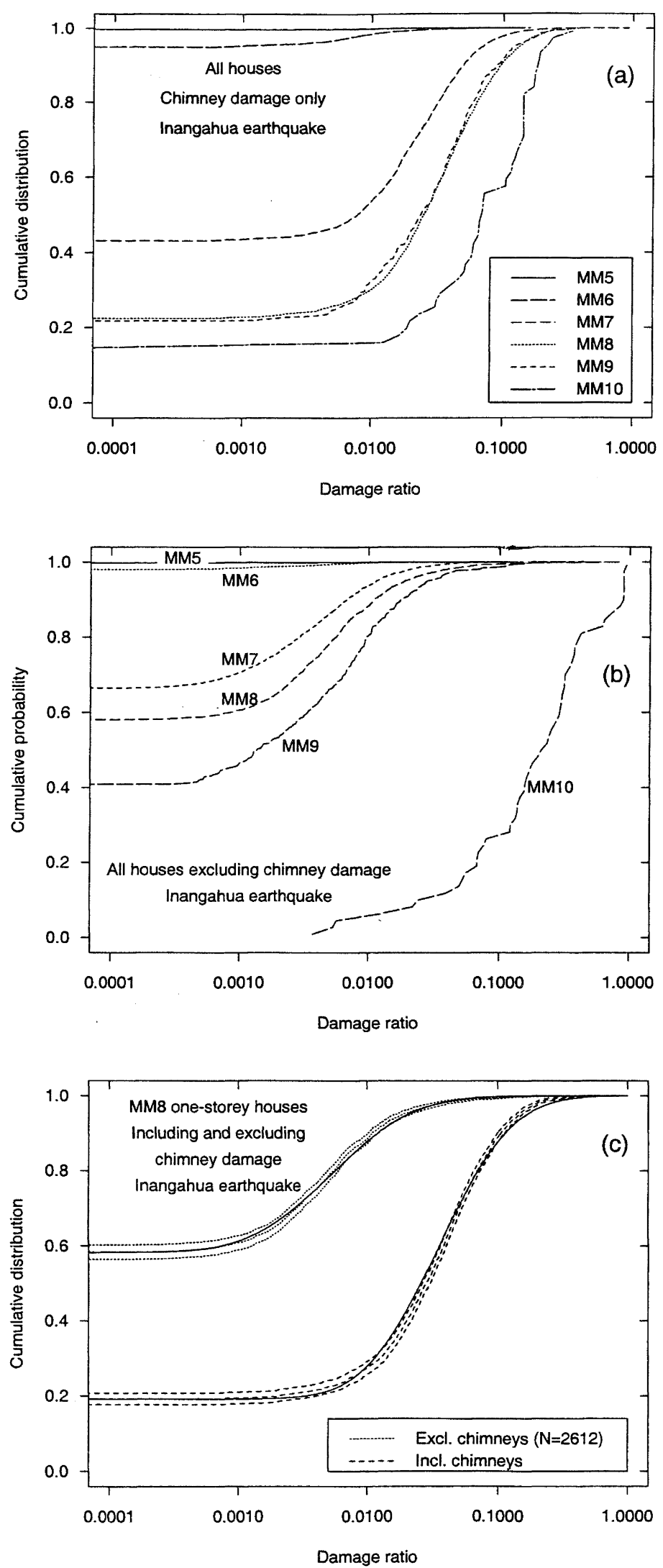

Figure 6: Three plots of cumulative probability distributions of damage ratio as a function of MM intensity for houses in the Inangahua earthquake: (a) One storey houses considering chimney related damage only, (b) All houses excluding chimney damage, and (c) One storey houses in the MM8 zone comparing cases including and excluding chimney damage. In (c), 95\% confidence limits for the empirical distribution and the fitted lognormal curves for one storey houses in the MM8 zone with and without chimney damage. 
Regarding the degree of chimney damage found here, it is of interest to note that in the magnitude $M_{W} 7.1$ Wairarapa earthquake of 24 June 1942, it may be inferred from Luke [13] that $20-25 \%$ of the 25,000 houses in Wellington suffered chimney damage. As Wellington was on the outer fringe of the MM7 intensity zone in that earthquake [23], this statistic is consistent with the value of $57 \%$ found for the whole of the MM7 zone in the present study.

In Figures 6(c) the fitted lognormal curves as expressed by $\mu$ and $\sigma$ in Tables 7 and 8 lie close to the empirical cumulative probability curves, though the fit is not quite as close as in previous studies [6-10]. It is noticeable that the fit at MM8 is better for the case where chimney damage is excluded than when it is included, and this was the case for the other intensity zones also. This is understandable, because chimney damage not only contributed a high proportion of the total, but was also less variable than the damage due to other causes. This means that the distribution of damage ratios including chimney damage is effectively a mixture of two distributions with different variances, which cannot be represented completely by the single variance parameter $\sigma$ of the lognormal model.

Next consider mean damage ratio as affected by brittle chimney damage. The influence of chimneys on $D_{r m}$ is very apparent in Figure 5(b) where $D_{r m}$ is seen to range from $2.0 \mathrm{x}$ $10^{-5}$ (excluding chimneys) at MM5 to 0.044 (including chimneys) at MM8 and then flattening off to rise only slightly to 0.046 at MM9. This plateau was explained above as a result of chimney damage reaching a near maximum at MM8. The dominance of brittle chimneys as an indicator of vulnerability is also illustrated by the ratio of $D_{r m}$ including chimneys with that excluding chimneys, which in round figures is $1.8,6,9,9,5$ and 1.2 for MM5 to MM10 respectively (Figure 7). The figure of 1.2 for the MM 10 zone is close to that of 1.3 obtained for the MM10 zone in Napier in 1931 [8] where all houses also had brittle chimneys, and were of similar construction (weatherboarded and piled) to those of the Inangahua area.

Finally, consider the effects of chimney damage on the percentage of houses damaged, as depicted in Figure 5(c). The ratio of the percentage damaged including chimney damage with that excluding chimney damage is $1.5,3.2,1.8$, $1.9,1.4$ and 1.0 for MM5 to MM10 respectively (Figure 7). For Napier (MM10 in 1931) [8], as in the Inangahua village area in 1968 , nearly all houses had damage other than that caused by chimneys, the above ratio being 1.01 . Considering the whole of the affected area (MM5 - MM10), the number of houses damaged would have been reduced by about $45 \%$ if no brittle chimneys had existed.

\subsection{Number of Storeys}

The vulnerabilities of houses of one and two storeys are compared at intensity MM7 and MM8 for the case when chimney damage is excluded. $D_{r m}$ and percentage of houses damaged with their associated $95 \%$ confidence limits are plotted on Figure 8 . It can be seen that at both MM7 and MM8, the values of both parameters are substantially greater for two storey houses than for one storey houses. The numbers of two storey houses in both intensity zones are however not large and the $95 \%$ confidence limits are quite wide. Nevertheless, the statistics $D_{r m}$ and percentage of two storey houses damaged are both significantly greater $(p<0.01)$ than those of one storey houses at MM7, as are also the averages of the MM7 and MM8 statistics, when chimney damage is excluded. Conversely, when chimney damage is included, the differences are not statistically significant.

The above findings are similar to those for one and two storey non-domestic buildings at intensities MM7 and MM9 in the Edgecumbe earthquake [9]

It is also noted that the above difference between the $D_{r m}$ values for one and two storey houses excluding chimney damage is hidden when chimney damage is included, as shown in Table 8.

\subsection{Damage ratio as a function of house value}

As has been done in previous studies [8,9], the possibility that damage levels vary with building value (or size) was examined. In Figure 9 the damage ratio for each house in the MM8 Zone is plotted against its replacement value, and a robust smooth trend line for mean damage ratio is fitted using the Splus local regression function "loess". When chimney damage is included, Figure 9(a), damage ratio is insensirive to size for larger houses, i.e. those with replacement values larger than the mean value of $\$ 7,000$ for the MM8 zone, but below that the damage ratio increases strongly with decreasing value. A similar trend was found for Napier houses at MM10 [8]. However when chimney costs are excluded, Figure 9(b), it is seen that damage ratio is insensitive to value (size) of houses. This is consistent with the findings [9] for one storey non-domestic buildings in the MM9 zone of the Edgecumbe earthquake.

\subsection{Effects of foundations}

In the MM10 zone there were three houses with full concrete foundations and three with partial foundations (at the corners only). These two subsets of houses had $D_{r m}$ of 0.035 and 0.18 respectively, which are both considerably less than the $D_{r m}$ of 0.35 for all the 55 houses for which $D_{r m}$ is dominated by houses with unbraced pile foundations (Figure $5(\mathrm{~b})$ ). The effects of foundations on house vulnerability at intensities MM7 - MM9 are being evaluated in an ongoing study.

\subsection{Household contents}

Plots of cumulative probability of damage ratio in the Inangahua earthquake are shown in Figure 10(a) for household contents for six intensity zones (MM5 - MM10), twice those (MM7 - MM9) that were possible in the studies $[6,7]$ of Edgecumbe earthquake. While very small amounts of damage do occur to contents at MM5 and MM6, Figure 10 (a) shows that the practical threshold of damage is at intensity MM7 for contents. This is one intensity unit higher than that observed for houses (Section 5.3).

As seen in Figure 10(b), $D_{r m}$ ranges gradually from $2 \times 10^{-6}$ at MM5 to 0.026 at MM9 before suddenly rising to 0.29 at MM10. This acute non-linearity of $D_{r m}$ with respect to intensity is akin to that of brittle structures. It appears that at MM10 a much greater proportion of household contents is overturned, or is damaged by parts of the buildings, than at MM9. 


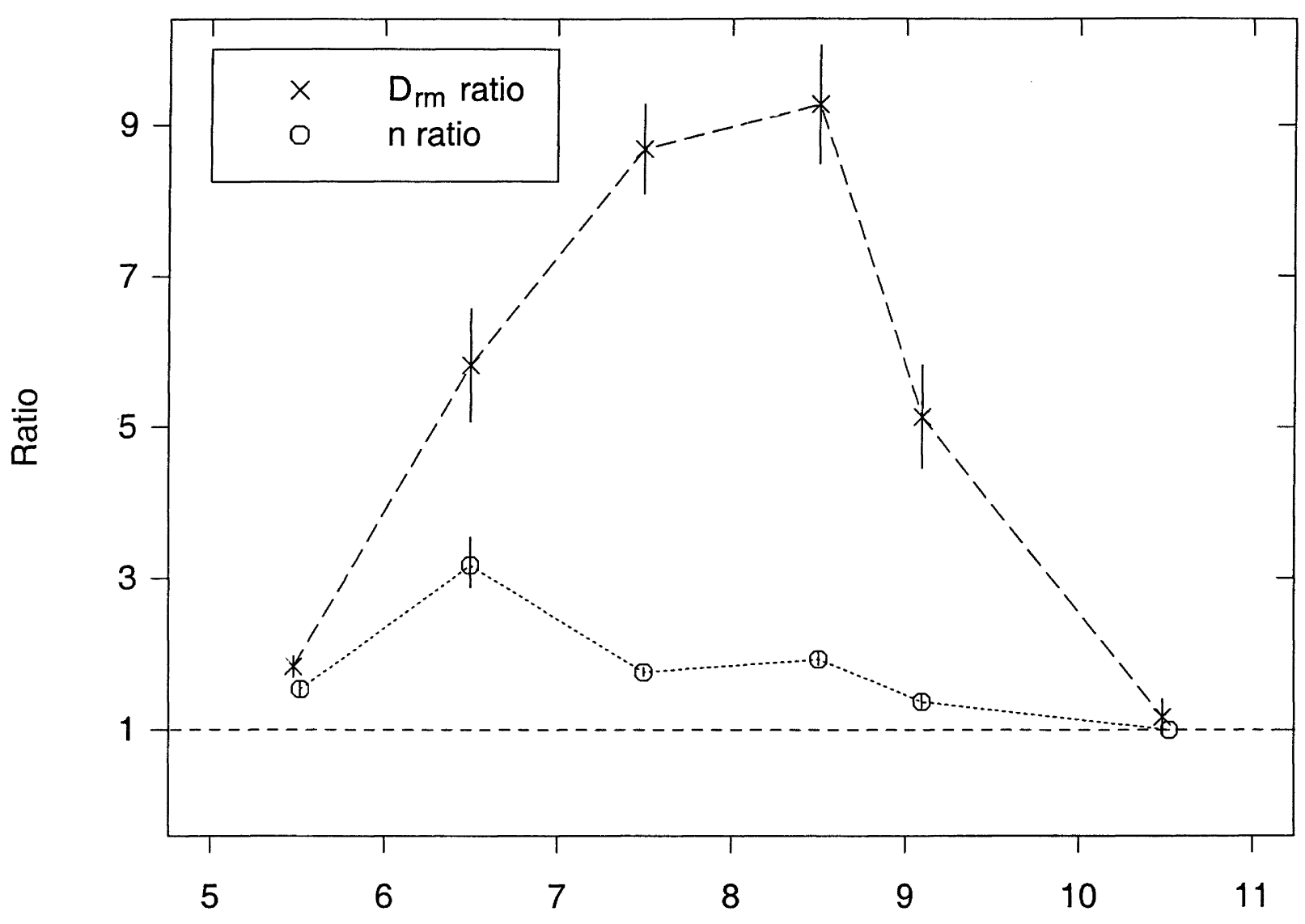

MM Isoseismal

Figure 7: $\quad$ Influence of chimneys on damage to houses as a function of intensity in the Inangahua earthquake. The $D_{r m}$ ratio is the ratio of $D_{r m}$ including chimney damage to $D_{r m}$ excluding chimney damage. The $n$ ratio is the ratio of $n / N$ including chimney damage to $n / N$ excluding chimney damage.

Some caution is needed when considering the mean damage ratio for MM10, as it comes from only one earthquake, is from a small population of only 53 households, and depends on the level of insured value in relation to the "present value" or other appropriate insured value for contents. However the mean damage ratio estimates appear to be reasonably robust in that all households are known to have suffered contents damage and the values of $D_{r m}$ and $\bar{D}_{r}$ at MM10 are very similar at 0.285 and 0.271 respectively. In addition these values are supported by a mean damage ratio of 0.21 for contents estimated from a sample of 57 European style houses near the centre of the 1995 Kobe earthquake. This information comes from proprietary insurance data (B. Shephard and D. Spurr, pers. comm.).

Finally the vulnerability of household contents is considered in terms of the percentage of contents parcels damaged, as plotted in Figure 10(c). It is seen that the percentage damaged for the Inangahua earthquake rises from very small at MM6 to $74 \%, 88 \%$ and $100 \%$ at MM8 - MM10 respectively.

\section{COMPARISONS WITH OTHER STUDIES}

In order to gain some understanding of inter-event variability of estimates of vulnerability for domestic property, comparisons are now made with the results of studies of other New Zealand earthquakes. The following comments are additional to some comparisons already made above. Of particular interest are the results of studies of the Edgecumbe earthquake $[6,7]$, for which purpose the values of the statistical parameters are tabulated here in Appendix 2 . Comparisons are made graphically in Figure 11 of mean damage ratio $D_{r m}$, and percentage damaged, together with their $95 \%$ confidence limits, for both houses and contents. Here the values for the MM9 zone are plotted at MM9.1 for the Inangahua earthquake (as discussed in Sections 3.2 and 5.2), while those for the MM9 zone of the Edgecumbe earthquake are plotted at MM9.4 for similar reasons as discussed elsewhere $[6,7]$. 

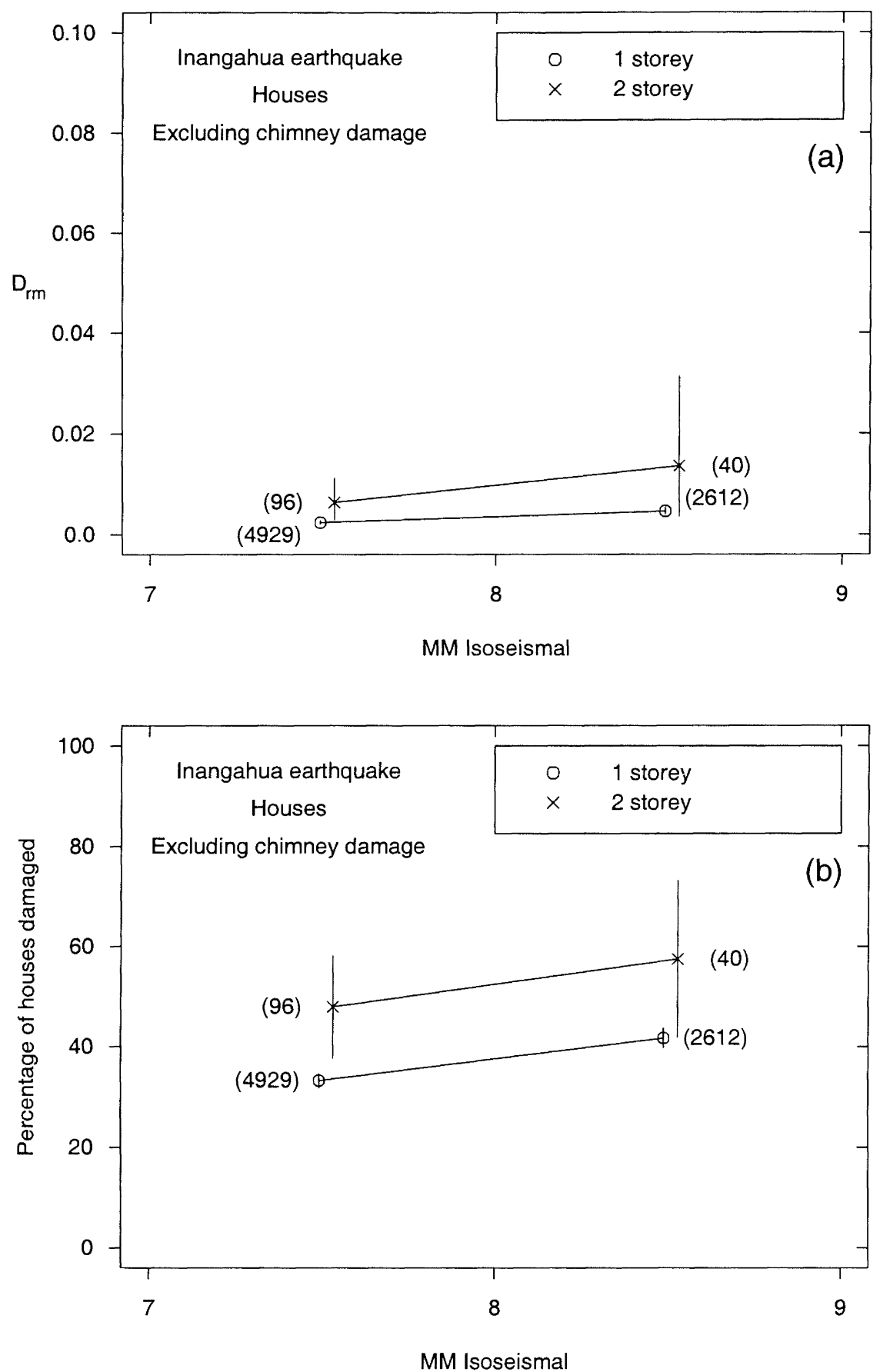

Figure 8: $\quad$ Two measures of the vulnerability of one and two storey houses in the MM7 and MM8 intensity zones of the Inangahua earthquake: (a) $D_{r m}$ and its $95 \%$ confidence limits, and (b) Percentage of houses damaged and its 95\% confidence limits. Note that there were not enough 2-storey houses in the MM9 and MM10 zones for similar comparisons to be made there.

As noted in Section 3.1, in the Inangahua earthquake the damage costs paid for houses were for repairs sufficient to return the building to its pre-earthquake condition (albeit somewhat meanly in some cases at MM10), with no participation by private sector insurers. In the Edgecumbe earthquake the EWDC's obligations were similar, being formally limited to repairs to "Indemnity Value", but the private insurers were widely underwriting the extra amount for full replacement cover. In practice however the private insurers' payouts were quite small, being $0.7 \%, 3.4 \%$ and $6.4 \%$ of the total losses at MM7. MM8 and MM9 respectively, as used in determining the mean damage ratios [7]. Regarding household contents, the authors consider the insurance assessment regimes to be the same for both earthquakes; private sector insurers were not involved in either case. Thus in insurance terms the damage ratios from these two earthquakes are derived from very similar cost data. 


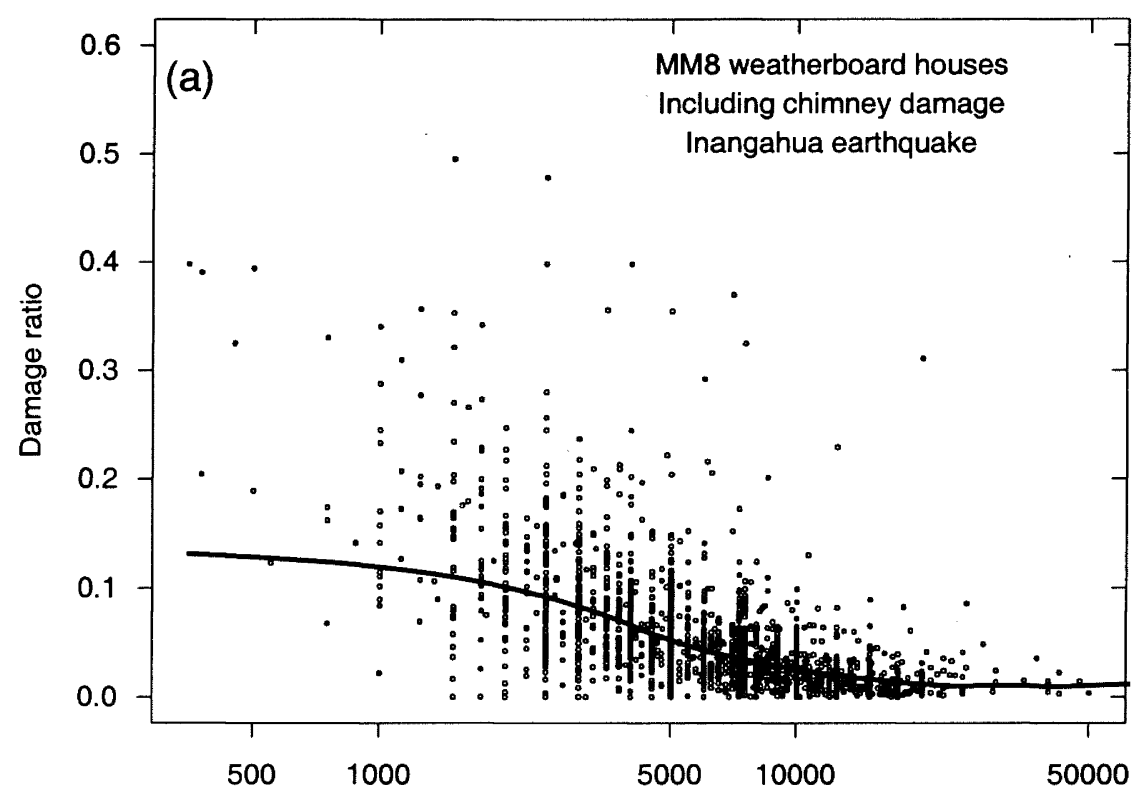

Replacement value (NZ dollars)

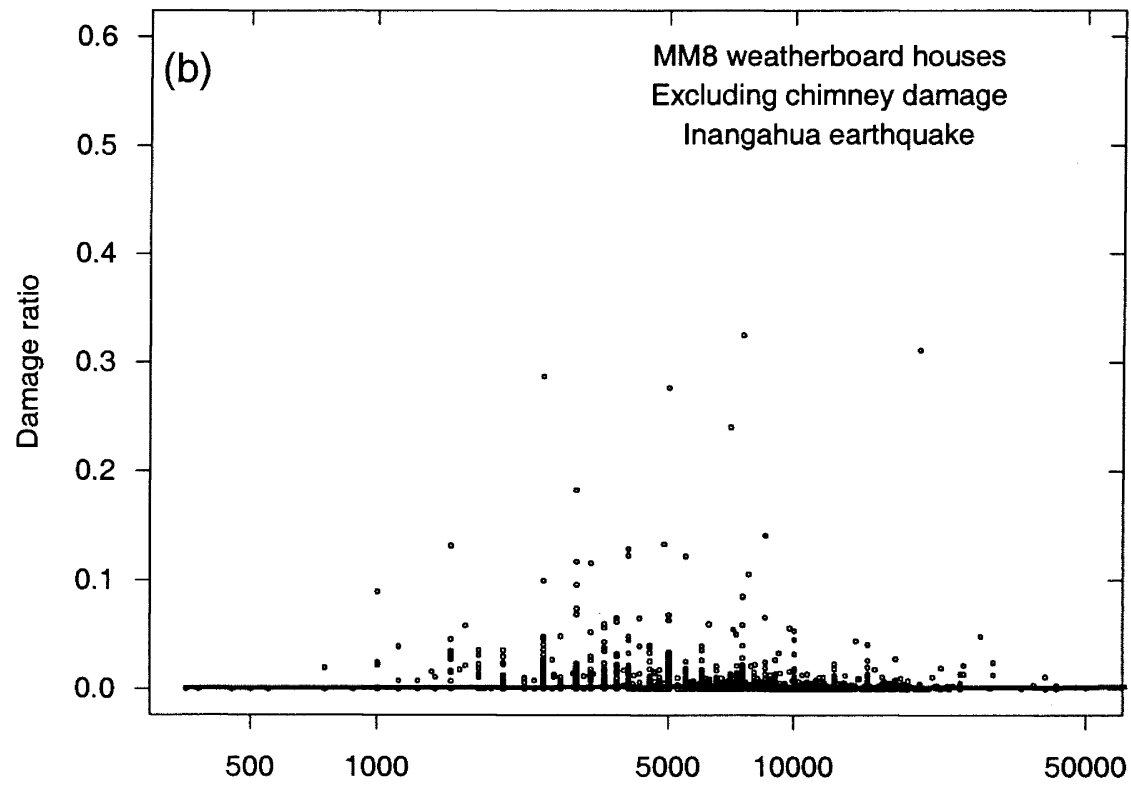

Replacement value (NZ dollars)

Figure 9: $\quad$ Plots of damage ratio versus insured value for one storey weatherboard houses in the MM8 intensity zone of the Inangahua earthquake, including a robust smooth trend line: (a) Including chimney damage, and (b) excluding chimney damage.

First, considering houses, it is noted that those affected by the Edgecumbe earthquake had fewer and generally more robust chimneys than was the case in the Inangahua earthquake. So it might be expected that $D_{r m}$ and $n / N$ for the Edgecumbe event would lie between the Inangahua results which exclude and include chimney damage. As seen on Figure 11(a) this is so for $D_{r m}$ at MM7 and MM8, but probably not at MM9, while for percentage of houses damaged (Figure 11(c)) this is true at MM8 and MM9 but not at MM7.

Second, considering contents, for $D_{r m}$ it is seen in Figure 11 (b) that the Inangahua and Edgecumbe values are very similar at MM6 - MM8. The Edgecumbe MM9 value is considerably greater than that of Inangahua $\left(D_{r m}=0.092\right.$ vs. 0.026 ), but this large difference seems to be largely explained by the strong non-linearity of the $D_{r m}$ vs. MMI function by plotting the Edgecumbe and Inangahua $D_{r m}$ values at MM9.4 and MM9.1 respectively. In contrast the percentages of contents parcels damaged (Figure 11(d)) are consistently lower for Edgecumbe at intensities $\geq \mathrm{MM} 7$, the Inangahua values being nearly twice those for Edgecumbe at MM7 and MM8 but only 1.1 times the Edgecumbe value at MM9. 

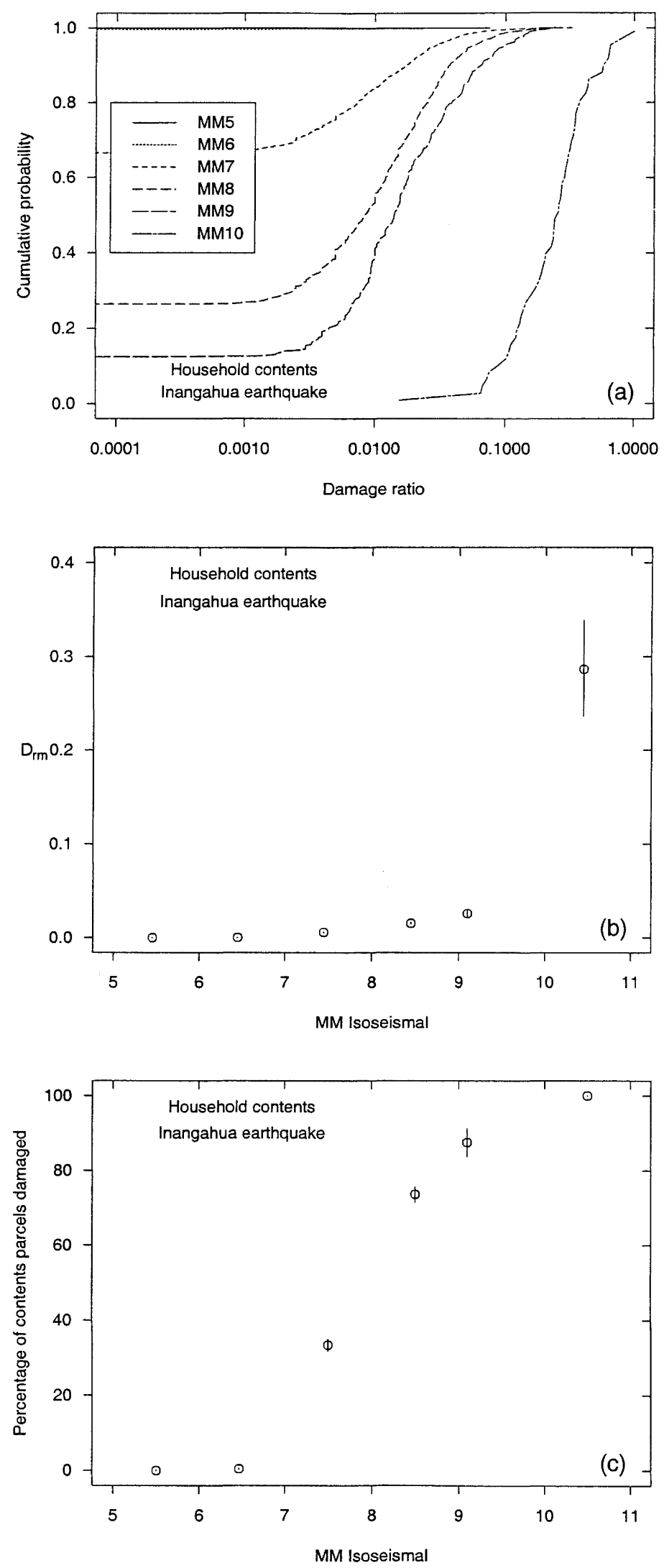

Figure 10: Three measures of vulnerability plotted as functions of MM intensity for household contents in the Inangahua earthquake: (a) Cumulative probability distributions of damage ratio, (b) $D_{r m}$ and its $95 \%$ confidence limits, and (c) Percentage of contents parcels damaged with its $95 \%$ confidence limits. 

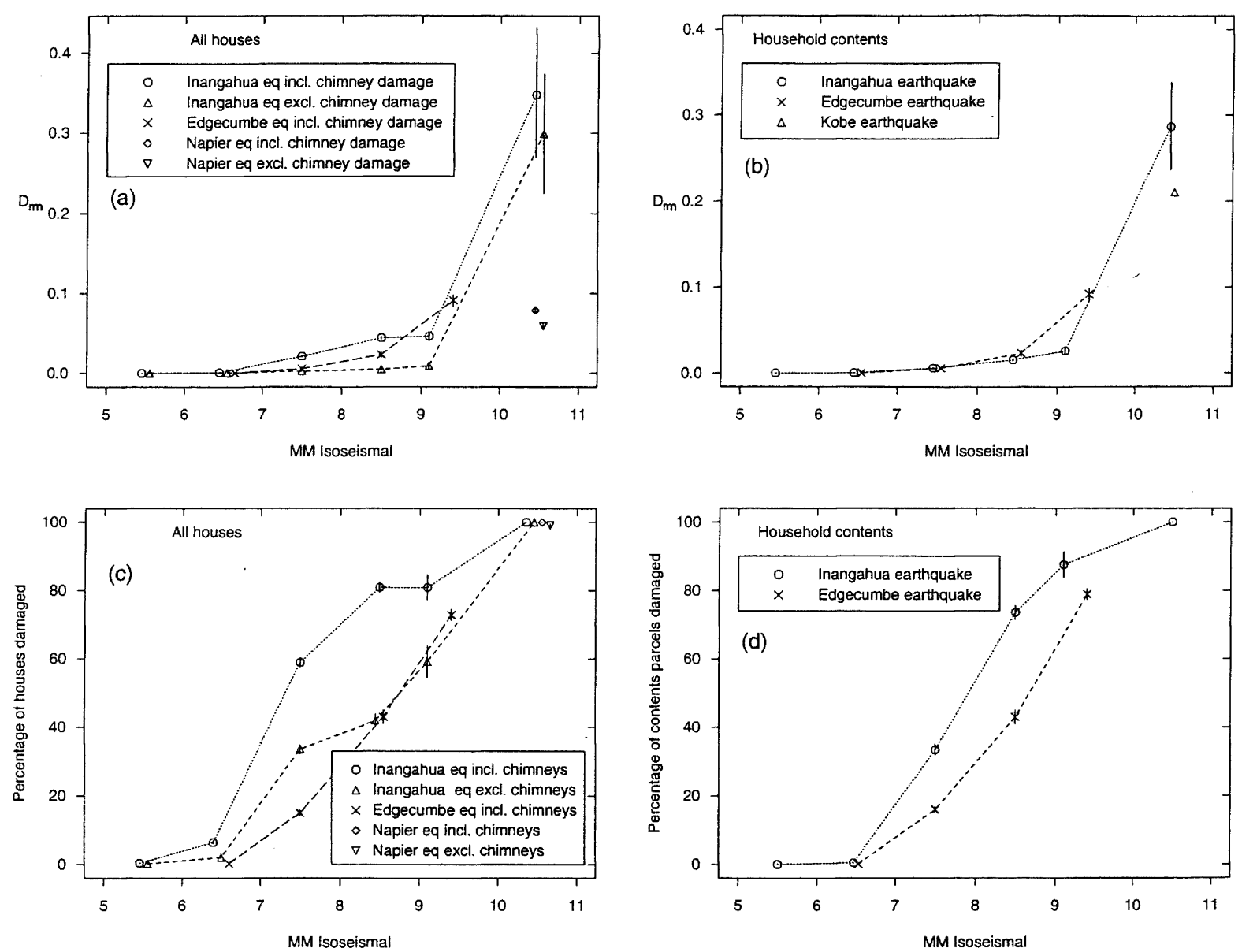

Figure 11: Vulnerability measures for domestic property from the Inangahua earthquake compared with those from other earthquakes: (a) $D_{r m}$ for houses, (b) $D_{r m}$ for contents, (c) Percentage of houses damaged, and (d) Percentage of contents parcels damaged.

Although the houses in the two locations were physically quite similar (mostly timber framed with weatherboards and unbraced piles), there was a wide discrepancy between $D_{r m}$ for houses at MM10 in 1968 for Inangahua $\left(D_{r m}=0.35\right)$ and in 1931 in Napier $\left(D_{r m}=0.09\right)$. This difference is considered to be partly a result of the very different financial circumstances prevailing in 1931 when there was no earthquake insurance and there was a severe economic depression. The two principal features of heavy damage in both places were severe chimney damage and many houses displaced from their piles. It is remarkable how cheaply repairs were made in Napier for foundation failure, whereas in Inangahua similar damage was relatively very expensive to repair or was considered to be not worth making good.

\section{APPLICATION OF THE RESULTS IN FUTURE STUDIES}

The damage ratios determined in this study are applicable directly to studies where the housing stock and insurance regime are similar to those prevailing in 1968 in the affected regions. For valid application to loss estimates for future earthquakes, the differences between the conditions outlined here and those of any other event will obviously need to be addressed, largely speculative as this process must necessarily be. The main factors to be taken into account are:

(i) The nature of the insurance policies in force. For example open-ended full replacement style policies seem likely to result in higher claims settlements than arose from the fixed sum insured policies that were prevalent in 1968 New Zealand. This difference is likely to occur mainly in cases with heavy damage.

(ii) The levels of insurance deductible that are likely to be in place. The damage costs adopted in this study include the deductible subtracted from the damage cost.

(iii) The possible inflationary effects of earthquakes causing very large total losses and leading to shortage of repair resources. The total direct damage cost for the Inangahua earthquake was about $\$(\mathrm{NZ}) 41$ million in 
year 2000 values, and hence was too small to cause such an effect.

(iv) The nature of the housing construction, i.e. incidence of brittle chimneys and nature of foundations. Further insights into the latter effect are being sought of an ongoing study due for completion in 2001 .

\section{CONCLUSIONS}

Arising from this study the following conclusions have been made:

\section{Houses (mostly timber framed)}

1. The vulnerability of domestic property has been determined in terms of probability distributions of damage ratio, mean damage ratio and percentage of property items damaged. This has been done over a range of six Modified Mercalli intensity zones (MM5 MM10) which is greater than in any previous study worldwide.

2. As in previous New Zealand studies the damage ratios were found to be modeled well by the lognormal distribution.

3. The total cost of damage to houses was $\$(\mathrm{NZ}) 1,503,000$ in 1968 values $(\$ 18,000,000$ in year 2000 values $)$. Nearly all houses had brittle chimneys, and it has been found that $78 \%$ of the above cost was due to chimney related damage.

4. The mean damage ratio including all costs exceeds that excluding chimney costs by factors of 6,9 and 9 at intensities MM7, MM8 and MM9 respectively.

5. The total number of houses damaged excluding chimney damage was $57 \%$ of that including chimney damage.

6. When chimney damage is included there is a plateau between MM8 and MM9 in the plots of $D_{r m}$ and percentage of houses damaged, $D_{r m}$ being 0.044 and 0.046 at MM8 and MM9 respectively. This is caused mainly by the dominance of chimney damage coupled with the near saturation of chimney damage at MM8.

7. The mean damage ratio is insensitive to house size when chimney damage is excluded, but when chimney damage is included the mean damage ratio is larger for small houses than for medium-sized or large houses.

8. When chimney damage was excluded, two storey houses were found to be significantly more vulnerable than one storey houses at intensity MM7, as previously found for non-domestic buildings in the Edgecumbe earthquake at MM7 and MM9.

9. In the MM10 zone the majority of houses were founded on unbraced piles and many fell off them suffering heavy damage, with $D_{r m}=0.35$. This accounts for the marked nonlinearity of $D_{r m}$ vs. intensity between MM9 and MMl0.

10. In the MM10 zone the three houses on concrete foundations suffered far less damage, with $D_{r m}=0.035$, while the three houses on partial concrete foundation had $D_{r m}=0.18$.

11. Although the houses in the two locations were physically quite similar, there was a wide discrepancy between $D_{r m}$ for houses at MM10 in 1968 for Inangahua $\left(D_{r m}=0.35\right)$ and in 1931 in Napier $\left(D_{r m}=0.09\right)$. This difference is considered to be partly a result of the very different financial circumstances prevailing in 1931 when there was no earthquake insurance and there was a severe economic depression.

12. When the lower incidence of brittle chimneys in the Edgecumbe earthquake is allowed for, $D_{r m}$ and $n / N$ for houses as found for that event and the Inangahua earthquake are consistent at most intensities.

\section{Household contents}

13. The effective threshold for damage to household contents was found to be at intensity MM7, while that for New Zealand houses was at MM6. These findings are consistent with the definitions of those intensities in the MM scale.

14. For household contents, the mean damage ratio plotted as a function of intensity is markedly non-linear between MM9 and MM10, $D_{r m}$ rising sharply to about 0.3 at MM10. This behaviour is akin to that of brittle structures, and household contents of course are mostly not designed to resist earthquakes.

15. In terms of mean damage ratio, the results for contents of this study and that of the Edgecumbe earthquake are very similar at intensities $\leq$ MM8, but at MM9 the $D_{r m}$ values seem to be consistent for the two events when the geographical distribution of houses within the two MM9 intensity zones are taken into account.

\section{ACKNOWLEDGEMENTS}

This study was funded by FRST under Contracts No's. C05506 and C05804, and by a complementary contribution from the Earthquake Commission (EQC). Data in the insurance claims made on the then-named Earthquake and War Damage Commission were made available to us at the National Archives and at the EQC's offices in Wellington. Thanks are also due to $\mathrm{J}$ Babor and $\mathrm{J}$ Cousins who assisted in the laborious task of extracting data from the claims, to $\mathbf{J}$ Cousins and $\mathrm{N}$ Perrin for their in-house reviews of the manuscript and also to D Spurr for a thoughtful external review.

In addition many people from the affected area helped by providing information on damaged and undamaged houses; in particular our thanks go to the following:

$\begin{array}{ll}\text { Inangahua: } & \text { W and R Inwood; Mrs F Stuart } \\ \text { Reefton: } & \text { M White } \\ \text { Murchison: } & \text { Mrs G Oxnam } \\ \text { Granity: } & \text { V Clementson } \\ \text { Greymouth: } & \text { B Brown } \\ \text { Hokitika: } & \text { E and J Walker } \\ \text { Karamea: } & \text { Mrs S. Lineham }\end{array}$




\section{REFERENCES}

1. Dowrick, D.J., and Rhoades D.A. (1998), "Magnitudes of New Zealand earthquakes, 1901 - 1993", Bulletin NZ National Society for Earthquake Engineering, 31(4), $260-280$

2. Anderson, H., Beanland, S., Blick, G., Darby, D., Downes, G., Haines, J., Jackson, J., Robinson, R. and Webb, T. (1994), "The 1968 May 23 Inangahua, New Zealand, earthquake: an integrated geological, geodetic, and seismological source model", N.Z. J. Geol. Geophys., 37, 59-86.

3. Dowrick, D.J., and Sritharan, S. (1993), "Peak ground accelerations recorded in the 1968 Inangahua earthquake and some attenuation implications", Bulletin NZ National Society for Earthquake Engineering, 26(3), 349-355.

4. Adams, R.D., Eiby, G.A., Lowry, M..A., Lensen, G.J., Suggate, R.P., and Stephenson, W.R. (1968), "Preliminary reports on the Inangahua earthquake, New Zealand, May 1968", Bulletin 193, New Zealand Department of Scientific and Industrial Research.

5. Dowrick, D.J., Gibson, G., and McCue, K. (1995), "Seismic hazard in Australia and New Zealand", Bulletin NZ National Society for Earthquake Engineering, 28(4), 279-287.

6. Dowrick, D.J., and Rhoades, D.A., (1990), "Damage ratios for domestic buildings in the 1987 Edgecumbe earthquake", Bulletin NZ National Society for Earthquake Engineering, 23, 137-149.

7. Dowrick, D.J. (1991), "Damage costs for houses and farms as a function of intensity in the 1987 Edgecumbe earthquake", Earthquake Engineering and Structural Dinamics, 20,455-469.

8. Dowrick, D.J., Rhoades, D.A., Babor, J., and Beetham, R.D. (1995), "Damage ratios and microzoning effects for houses in Napier at the centre of the magnitude 7.8 Hawke's Bay, New Zealand, earthquake of 1931", Bulletin NZ National Society for Earthquake Engineering, 28(2), 134-145.

9. Dowrick, D.J., and Rhoades, D.A. (1997), "Vulnerability of different classes of low-rise buildings in the 1987 Edgecumbe, New Zealand, earthquake", Bulletin NZ National Society' for Earthquake Engineering, 30(3), 227-241.

10. Dowrick, D.J., and Rhoades, D.A. (1997), "Inferences for design, insurance and planning from damage evaluation in past New Zealand earthquakes", Journal of Earthquake Engineering, 1(1), 77-91.

11. Rhoades, D.A., and Dowrick, D.J. (1999), "Variability of damage ratios for property in earthquakes". Earthquake Spectra, 15(2), 297-316.
12. Grant-Taylor, T.L., Adams, R.D., Hatherton, T., Milne, J.D.G., Northey, R.D., and Stephenson, W.R. (1974), "Microzoning for earthquake effects in Wellington N.Z." New Zealand Department of Scientific and Industrial Research, Wellington, Bulletin 213.

13. Luke, K.E. (1943), "City of Wellington, N.Z. Report on damage by earthquakes". (Unpublished) City Engineer's report to Wellington City Council.

14. Rojan, C. and Sharpe, R.L. (1985), "Earthquake damage evaluation data, ATC-13". Applied Technology Council, California.

15. "The New Zealand Census 1966", Department of Statistics, New Zealand.

16. Bird, D.I.D. (1969), "Insurance assessments in Inangahua". Bulletin NZ Society for Earthquake Engineering, 2(1), 111-112.

17. Suggate, R.P. and Wood, P.R. (1979), "Inangahua earthquake - damage to houses", Report N.Z.G.S. 85, New Zealand Geological Survey, Department of Scientific and Industrial Research.

18. "The New Zealand Official Year Book 1969", Department of Statistics, New Zealand.

19. Various authors (1968), "The 1968 Inangahua earthquake", Conference seminar papers, Bulletin NZ Society for Earthquake Engineering, 1(2), 4-96.

20. Various authors (1969), "A preliminary report on the Inangahua earthquake New Zealand, May 24, 1968", Bulletin NZ Society for Earthquake Engineering, 2(1), 9-148.

21. Shepherd, R., Bryant, A.H., Carr, A.J., Dodd, T.A.H., Gordon, D.R., Moss, P.J., and Sutherland, A.J. (1970), "The 1968 Inangahua earthquake", Canterbury Engineering Journal, 1, 2-86.

22. Dowrick, D.J. (1996), "The Modified Mercalli earthquake intensity scale - Revisions arising from recent studies of New Zealand earthquakes". Bulletin $N Z$ National Society for Earthquake Engineering, 29(2), 92-106.

23. Downes, G.L., Dowrick, D.J., Van Dissen, R.J., Taber, J.J, Hancox, G.T., and Smith, E.G.C. (2001), "The 1942 Wairarapa, New Zealand, earthquakes: analysis of observational and instrumental data". Bulletin NZ Society for Earthquake Engineering, 34(2), 125-157. 
APPENDIX 1: $\quad$ Extracts from the New Zealand 1996 Modified Mercalli intensity scale relating to pre-1969 property [22]. Criteria for MM5 - MM10 relating to fittings (contents) and structures, (essentially the same as the New Zealand $1966 \mathrm{MM}$ intensity scale).

\section{MM5 Fittings}

Small unstable objects are displaced or upset. Some glassware and crockery may be broken.

Structures

Some windows Type 1 cracked.

A few earthenware toilet fixtures cracked.

\section{MM6 Fittings}

Objects fall from shelves

Pictures fall from walls.

Glassware and crockery broken.

Very unstable furniture overturned.

Structures

Slight damage to Buildings Type I.

Some stucco or cement plaster falls.

Windows Type I broken.

Damage to a few weak domestic chimneys, some may fall.

\section{MM7 Fittings}

Substantial damage to fragile contents of buildings.

Structures

Unreinforced stone and brick was cracked.

Buildings Type I cracked some with minor masonry falls.

A few instances of damage to Buildings Type II.

Unbraced parapets, unbraced brick gables, and architectural ornaments fall.

Roofing tiles, especially ridge tiles may be dislodged

Many unreinforced domestic chimneys damaged, often falling from roof-line.

Water tanks Type I burst.

A few instances of damage to brick veneers and plaster or cement-based linings. Unrestrained water cylinders (Water Tanks Type II) may move and leak.

Some windows Type II cracked. Suspended ceilings damaged.

\section{MM8 Structures}

Buildings Type I, heavily damaged, some collapse

Buildings Type II damaged, some with partial collapse. Buildings Type III damaged in some cases.

A few instances of damage to Structures Type IV.

Monuments and pre-1976 elevated tanks and factory stacks twisted or brought down.

Some pre-1965 infill masonry panels damaged

Decayed timber piles of houses damaged.

Houses not secured to foundations may move.

Most unreinforced domestic chimneys damaged, some below roof-line, many brought down.

\section{MM9 Structures}

Many Buildings Type I destroyed.

Buildings Type II heavily damaged, some collapse.

Buildings Type III damaged, some with partial collapse.
Structures Type IV damaged in some cases, some with flexible frames seriously damaged.

Houses not secured to foundations shifted off

Brick veneers fall and expose frames.

\section{MMIO Structures}

Most Buildings Type 1 destroyed.

Many Buildings Type II destroyed.

Buildings Type III heavily damaged, some collapse.

Structures Type IV damaged, some with partial collapse.

Some well-built timber buildings moderately damaged (excluding damage from falling chimneys).

\section{Construction Types:}

Buildings Type I (Masonry D in the NZ 1966 MM scale) Buildings with low standard of workmanship, poor mortar, or constructed of weak materials like mud brick or rammed earth. Soft storey structures (e.g. shops) made of masonry, weak reinforced concrete, or composite materials (e.g. some walls timber, some brick) not well tied together.

Buildings Type II (Masonry $C$ in the NZ 1966 MM scale) Buildings of ordinary workmanship, with mortar of average quality. No extreme weakness, such as inadequate bonding of the corners, but neither designed nor reinforced to resist lateral forces

Buildings Type III (Masonry B in the NZ 1966 MM scale) Reinforced masonry or concrete buildings of good workmanship and with sound mortar, but not formally designed to resist earthquake forces.

Structures Type IV (Masonry' A in the NZ 1966 MM scale) Buildings [and bridges] designed and built to resist earthquakes to normal use standards, i.e. no special collapse or damage limiting measures taken [mid1930's to 1970's]. 
APPENDIX 2: $\quad$ Basic statistics of damage ratio for houses and household contents in the 1987 Edgecumbe earthquake.

In the study of damage to domestic property in the Edgecumbe earthquake $[6,7], \bar{D}_{r}$ was estimated, but $D_{r m}$ has not been estimated till now. The full list of basic statistics including both definitions of mean damage ratio are therefore tabulated below.

\begin{tabular}{|c|c|c|c|c|c|c|}
\hline & $n$ & $N$ & $\mu$ & $\sigma$ & $D_{r m}$ & $\bar{D}_{r}$ \\
\hline \multicolumn{7}{|l|}{ MM6 Zone } \\
\hline - Houses & c. 50 & 16400 & $\nabla$ & $\nabla$ & $\nabla$ & 0.0001 \\
\hline - Contents & & & $\nabla$ & $\nabla$ & $\nabla$ & 0.0001 \\
\hline \multicolumn{7}{|l|}{ MM7 Zone } \\
\hline - Houses & 1100 & 7300 & -4.30 & 1.44 & 0.0056 & 0.0063 \\
\hline - Contents & 1170 & 7300 & -3.91 & 1.17 & 0.0063 & 0.0056 \\
\hline \multicolumn{7}{|l|}{ MM8 Zone } \\
\hline - Houses & 1075 & 2500 & -3.92 & 1.45 & 0.023 & 0.021 \\
\hline - Contents & 1075 & 2500 & -3.81 & 1.15 & 0.018 & 0.015 \\
\hline \multicolumn{7}{|l|}{ MM9 Zone } \\
\hline - Houses & 2040 & 2800 & -3.25 & 1.38 & 0.091 & 0.070 \\
\hline - Contents & 2210 & 2800 & -2.80 & 1.18 & 0.092 & 0.079 \\
\hline
\end{tabular}

$\nabla$ Indicates not calculated 